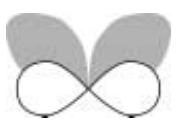

\title{
Grasslands, heathlands and shrublands in coastal New England: historical interpretations and approaches to conservation
}

Glenn Motzkin* and David R. Foster Harvard Forest, Harvard University, Petersham, MA, USA

\section{Abstract}

Aim This study evaluates the long-term history of grassland, heathland and shrubland communities that are high priorities for conservation in the north-eastern US and support numerous globally rare species. Such an historical perspective is necessary in order to develop appropriate conservation and management approaches for these communities.

Location The study area encompasses the coastal region that extends from Cape Cod, MA to Long Island, NY, including the islands of Nantucket, Martha's Vineyard, and Block Island.

Methods In order to determine whether open-land habitats occurred in the study region prior to European arrival in the seventeenth century and to assess changes to these communities through the historical period, a wide range of palaeoecological, archaeological, ethno-historical, biological and field data were reviewed. Information about the history of human impacts on these communities was used to interpret landscape change over time and to evaluate current and potential conservation and management approaches.

Results The region was predominantly wooded prior to widespread Euro-American land clearing beginning in the seventeenth century, with some areas of early successional habitats, primarily on exposed sites and near Native American settlements. Grasslands, heathlands and shrublands increased dramatically as a result of intensive and primarily agricultural disturbance through the historical period. The decline in recent decades of these communities results from extensive residential and commercial development, and from widespread abandonment of traditional agricultural practices, especially intensive grazing.

Main conclusions Despite considerable uncertainty as to the pre-European distribution and abundance of species characteristic of grasslands, heathlands and shrublands, historical disturbances have been sufficiently widespread and severe that it is unlikely that modern species assemblages closely resemble those that occurred prior to European arrival. Management aimed at perpetuating early successional species assemblages on sites other than exposed, coastal locations may require use of traditional land-use practices or appropriate substitutes of comparable intensity.

\section{Keywords}

Barrens, grasslands, heathlands, rare species, shrublands, coastal New England.

\footnotetext{
*Correspondence: Harvard Forest, Harvard University, P. O. Box 68, Petersham, MA 01366 USA. E-mail: gmotzkin@fas.harvard.edu
} 


\section{INTRODUCTION}

Across the eastern US and much of Europe, an under-appreciated trend in temperate biodiversity is occurring: species occupying open-land habitats are declining at a precipitous rate. In the US, although much concern is directed towards maintaining interior forest species and managing species that have benefited from recent increases in native forests (e.g. Medeiros, 1992), the plants and animals characteristic of grasslands, heathlands, shrublands and early successional forests are in much greater jeopardy of local extirpation. Conservation interest in early successional habitats in the Northeast is focused on the coastal region that extends from Cape Cod, Massachusetts to eastern Long Island, New York, including Nantucket, Martha's Vineyard, Block Island and the Elizabeth Islands (Fig. 1). This region is characterized by a common geological and human history, environment, soils and biota (Patterson et al., 1983; Fletcher \& Roffinoli, 1986; Dunwiddie, 1992; Dunwiddie \& Adams, 1994; Bragdon, 1996; Stevens, 1996; Dunford \& O’Brien, 1997; Chilton 2002). Importantly, coastal grasslands, heathlands and shrublands in this region support the greatest concentrations of rare or uncommon species in the Northeast and are among the highest priorities for national, regional and local conservation agencies (Carlson et al., 1991; The Trustees of Reservations (TTOR), 1999; Steel, 1999; Beers \& Davison, 1999; MNHESP, 2001).

Despite aggressive and remarkably expensive protection of portions of the coastal region from residential and commercial development, many characteristic early successional species and habitats continue to decline. In large measure, these habitats are being lost because of invasion and spread of aggressive, although primarily native, shrubs and trees (Dunwiddie, 1994). Similar successional trends are noted on many open lands worldwide (Watkins, 1993; Sutherland \& Hill, 1995; Leach \& Givnish, 1996). This pattern of widespread habitat deterioration and species loss raises funda- mental questions regarding the underlying forces of change, the long-term nature of the habitats and species assemblages, and the potential to identify effective management approaches to counteract these trends.

In New England, management efforts by conservation agencies attempting to maintain and restore early successional habitats have emphasized prescribed burning. This approach is largely based on the rationale that: (1) nonforested communities are thought to be native habitats that were maintained prehistorically by natural and Native American fire and land-use practices (e.g. Barbour et al., 1998; TNC, unpublished manuscript; Vickery, 2002), and (2) fire was common in the region in the nineteenth and early twentieth centuries but has been dramatically reduced in recent decades as a result of improved fire detection and suppression. Over the past two decades, prescribed fire has been applied to many coastal grasslands, shrublands and heathlands in the region, with mixed success at restricting the incursion of woody species and maintaining populations of uncommon species (Niering \& Dreyer, 1989; Dunwiddie, 1998; TNC, unpublished manuscript; Vickery, 2002). Despite a well-documented history of land-use and landcover transformations over the past three centuries that greatly increased the extent of non-forested communities (Dunwiddie, 1989; Foster \& Motzkin, 1999; Eberhardt et al., 2003), a strong and largely untested belief persists on the part of many ecologists and conservationists that these assemblages are 'natural' and have a lengthy lineage into preEuropean times (Leahy et al., 1996; Askins, 1997, 2000; Barbour et al., 1998). Importantly, these interpretations of ecological history and the nature of the pre-European landscape are major drivers of modern conservation policy and practice.

In this paper, we evaluate several lines of evidence that provide insight into the nature of the landscape of coastal New England prior to European settlement and the processes that could have enabled upland grasslands, heathlands (i.e.

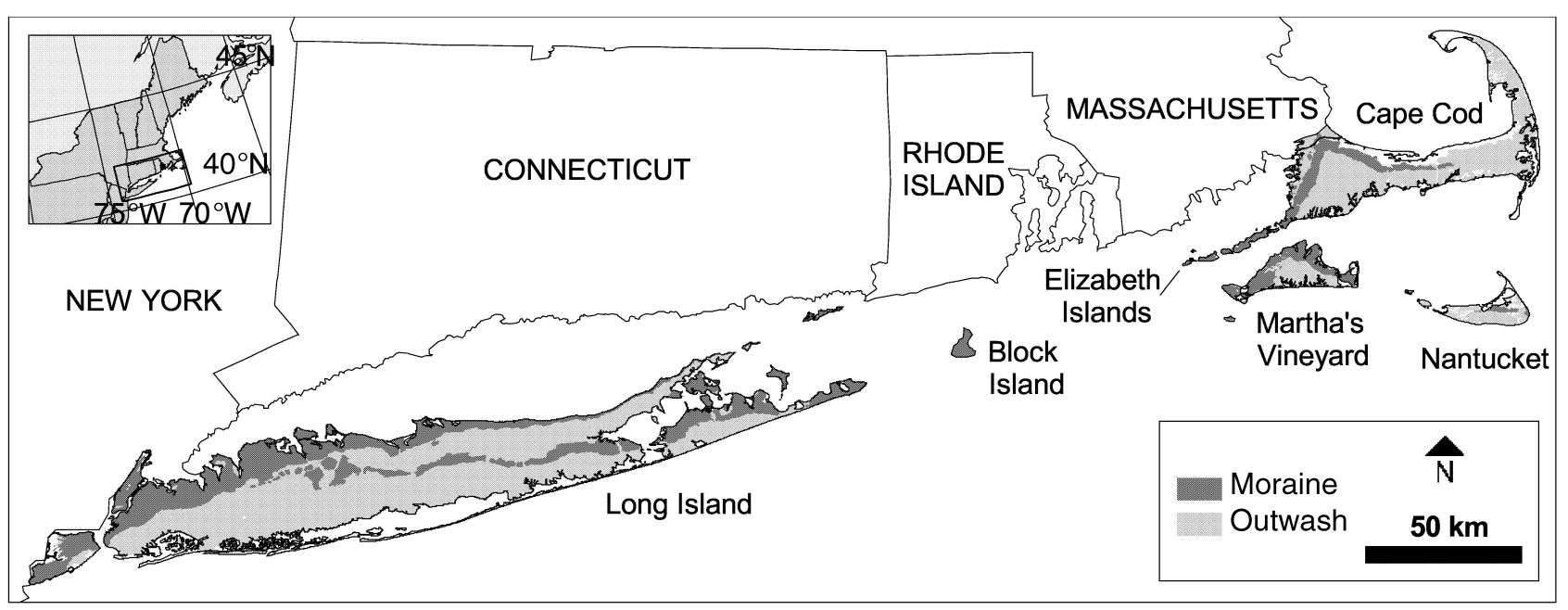

Figure I Map of the coastal study region from Cape Cod, MA to Long Island, NY. 
areas dominated by dwarf shrubs) and shrublands (i.e. thickets dominated by Quercus ilicifolia or other tall shrubs) to develop and persist. First, we consider palaeoecological, archaeological, ethnographic and ecological data that have been interpreted as suggesting that extensive non-forested areas occurred in the region prior to the seventeenth century. Although several previous studies have evaluated Native American and fire influences on the pre-European landscape in the Northeast (e.g. Day, 1953; Martin, 1973; Cronon, 1983; Russell, 1983; Patterson \& Sassaman, 1988; Whitney, 1994), none have explicitly addressed the link between interpretations of ecological history and modern conservation and management efforts. In order to address this issue, we briefly review the history of land cover changes during the historical period. Next, we discuss our interpretation of preand post-European landscape changes and propose conservation and management approaches that we believe accurately incorporate an understanding of the long-term history of the region. Finally, we suggest that the conclusions drawn from an examination of open-land vegetation indicate commonality in many of the challenges facing conservation in north-eastern North America, north-western Europe and other temperate regions. In particular, maintaining highly dynamic cultural landscapes presents major challenges, particularly with increasing societal emphasis on the value of 'natural' systems and the importance of natural processes.

\section{EVIDENCE FOR OPEN-LAND VEGETATION AND ITS DRIVERS}

\section{The Pre-European landscape}

Palaeoecological data from numerous studies confirm that most of north-eastern North America, including New England, was predominantly forested prior to European settlement in the seventeenth and eighteenth centuries (McAndrews, 1988; Foster et al., 1998; Fuller et al., 1998; Russell \& Davis, 2001). Available palaeoecological data from Cape Cod, Martha's Vineyard, Nantucket, Block Island and Long Island suggest that the coastal region was also largely forested prior to widespread clearing for historical agriculture (Ogden, 1958, 1961; Winkler, 1985; Patterson \& Backman, 1988a; Dunwiddie, 1990a; Jackson \& Dunwiddie, 1992; Tzedakis, 1992; Stevens, 1996; Foster et al., 2002a; Parshall et al., 2003). For instance, on Cape Cod, Parshall et al. (2003) found no palaeoecological evidence for pre-European grasslands or heathlands. Rather, their results suggest that the peninsula was heavily forested and that composition varied geographically as a consequence of edaphic factors, fire frequency and exposure. Similarly, Dunwiddie's (1990a) interpretations of pollen diagrams from Nantucket and Block Island suggest that prior to European arrival, the coastal islands were wooded with oaks and other trees and that heath and grassland vegetation was restricted to limited areas adjacent to the coast where chronic wind disturbance and salt spray limited tree growth. On Martha's Vineyard, palaeoecological data suggest that the island was also largely wooded prior to European settlement (Ogden, 1958; Stevens, 1996;
Foster et al., 2002a), although arboreal pollen percentages from lake sediments on an extensive outwash plain are substantially lower than those recorded from Cape Cod and Block Island, raising the possibility that portions of Martha's Vineyard may have been less forested than these areas (Dunwiddie, 1990a; Stevens, 1996).

Palaeoecological reconstructions also provide insight into the importance of grasslands in the region over time. For most portions of the coastal region, including Cape Cod, Block Island, Nantucket and the morainal areas of Martha's Vineyard, pre-European grass pollen percentages are very low (typically $<1-4 \%$ ), suggesting the absence or limited importance of these habitats (Fig. 2). However, higher (5-20\%) pre-European grass pollen percentages were recorded for several cores from Martha's Vineyard (Stevens, 1996; Foster et al., 2002a), indicating that grasslands or other communities with high grass abundance may have been locally important (Jacobson \& Grimm, 1986; Stevens, 1996; Sugita et al., 1999). The relative contribution of upland vs. wetland grass species to these high pre-European pollen values is unknown.

\section{Requisite disturbance processes}

Given the moist-temperate environment of New England, ecologists agree that chronic or intense disturbance is necessary to prevent the development of forests across essentially all upland areas (Raup, 1937; Whitney, 1994; Foster \& O'Keefe, 2000). Is it likely that natural disturbance or Native American activity provided sufficient disturbance to generate and maintain extensive grasslands or other non-forested habitats in the pre-European period?

Fire is perhaps the primary natural disturbance that could potentially generate persistent early successional habitats in the Northeast, although the likelihood for rapid sprouting or re-colonization by trees after fire suggests that extremely short fire return intervals (high fire frequencies), perhaps in combination with occasional high severity fires, would be required to maintain extensive non-forested areas. Because lightning is typically accompanied by heavy rain in the Northeast, it is highly unlikely that lightning-ignited wildfires were sufficiently frequent to generate or maintain extensive grasslands in the pre-European period (Patterson \& Sassaman, 1988). However, Native Americans potentially could have generated a range of early successional communities, through burning, agriculture or other land-use practices. Evaluating long-term Native American influence on the landscape involves interpretation of the lifestyle, subsistence base and population size of pre-European human societies. In such an analysis, it is necessary to distinguish between archaeological evidence of pre-European Native American subsistence and settlement patterns vs. ethno-historical evidence of Native American activity after contact with Europeans (which we address below), as there is strong disagreement between the early historical record and earlier archaeological evidence. Previous studies suggesting that Native Americans generated extensive open vegetation in coastal New England interpret Late Woodland 


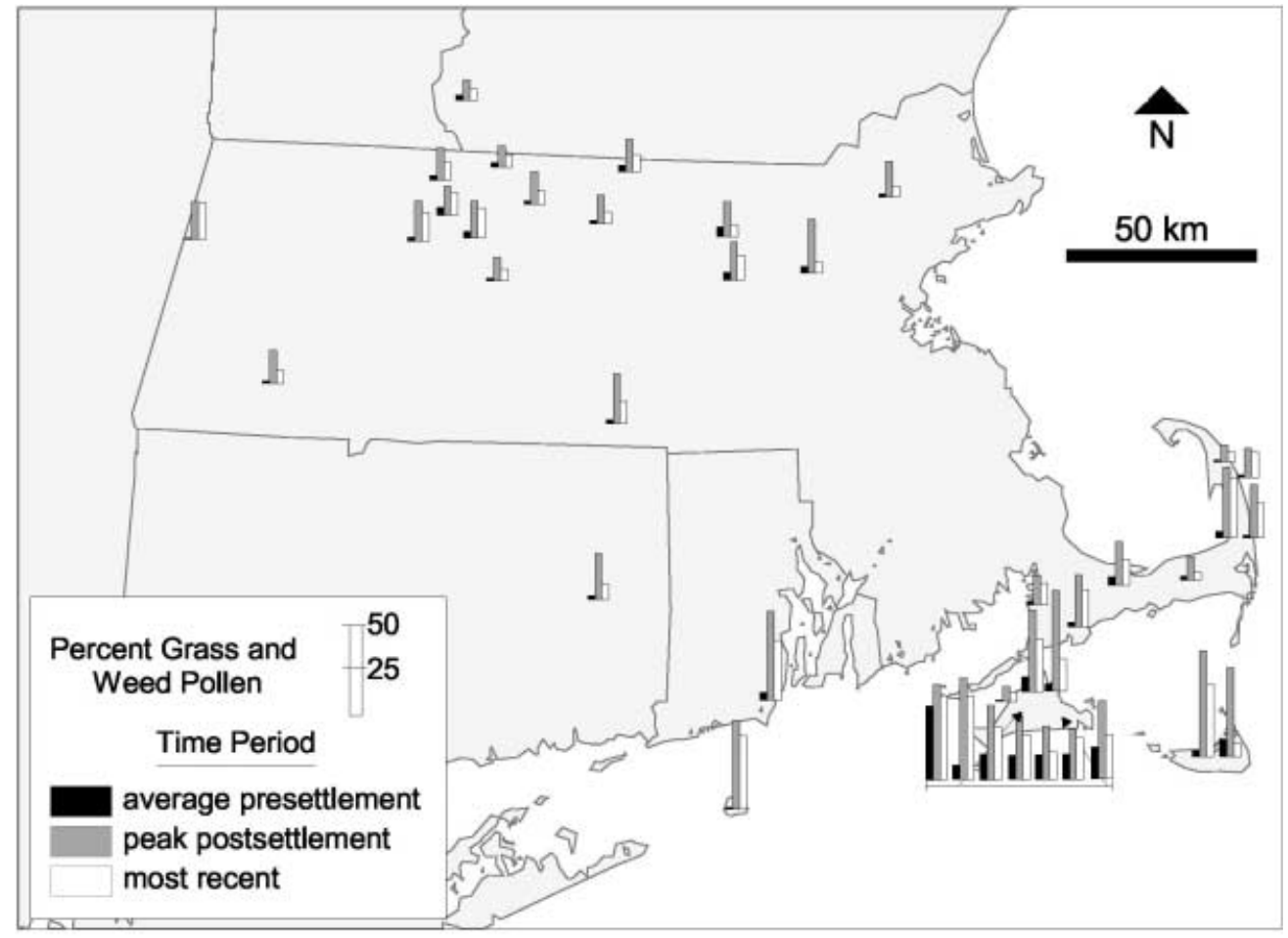

Figure 2 Comparison of grass and weed pollen abundance from sediment cores in southern New England for the pre-European, historical and modern periods. Pre-European settlement values are calculated as the average of the five samples immediately preceding European settlement; modern values represent the average of the two most recent samples. Values are the percentage of the upland pollen sum, and weeds include Artemisia, Ambrosia, Tubuliflorae, Liguliflorae, Caryophyllaceae, Chenopodium, Plantago, Rumex, and Polygonaceae. Data are from Bernabo (1977), Whitehead (1979), Backman (1984), Dunwiddie (1989, 1990a), Stevens (1996), Fuller et al. (1998), Parshall et al. (2003), Foster et al. (2002), and Harvard Forest (unpublished data).

societies as occupying semi-permanent villages in which concentrated populations depended on maize agriculture and modified large areas (Cronon, 1983). However, archaeological support for such an interpretation of the subsistence base or social structure of Native populations prior to European contact is weak (MHC, 1987; Luedtke, 1988; Thorbahn, 1988; Carlson et al., 1992; Bernstein, 1993; Bragdon, 1996; Chilton, 1999; Chilton, 2002). Whereas early historical descriptions suggest the presence of concentrated Native American settlements with large permanent structures, extensive corn fields, and fortified village centres, archaeological evidence from the period prior to European contact only confirms the existence of small temporary shelters supporting seasonal occupation. There is no evidence in New England of structures or concentrated settlements comparable with those that occurred in New York and Ontario, where Native Americans undertook broad-scale land clearance and agriculture that greatly modified the forested landscape (McAndrews, 1988). Archaeological data in New England also provide no signs of pre-European fortified structures, intertribal warfare or large food caches (Chilton, 1999; Chilton et al., 2002). In contrast, available data suggest that Late Woodland Native Americans relied on a broad-based hunter-gatherer subsistence strategy that varied among coastal, riverine and upland areas (Bragdon, 1996; Bendremer, 1993; Bernstein, 1993). In the coastal region, Native Americans relied on diverse marine and upland wildlife and plant resources, supplemented by horticulture of squash, beans, maize and other crops. Rather than being intensive agriculturists, this lifestyle involved at least some seasonal mobility, leading to the characterization of Native Americans in the region as 'mobile farmers' (Chilton, 1999), with subsistence strategies characterized as 'conditional sedentism' (Bragdon, 1996), 'broad spectrum and seasonally mobile' (Carlson et al., 1992), 'tethered mobility' (Heckenberger et al., 1992), and 'dispersed and non-nucleated' (Luedtke, 1988). Widespread questioning of the concept of permanent, agriculturally based populations prior to European contact prompted a conference devoted to the question 'Where are the Late Woodland Villages in southern New England?' The consensus was that there was no evidence of their existence (Luedtke, 1988).

Even in the absence of concentrated agricultural societies along the coast prior to European contact, Native American impacts on the landscape might still have been substantial if population densities were sufficiently high and if there was heavy reliance on practices such as widespread burning. Several authors have attempted to estimate Native American population densities across New England in the early 
seventeenth century based on historical descriptions and information on settlement patterns (e.g. Cook, 1976; Whitney, 1994). Although the relationship between population size in the early seventeenth century and earlier periods (e.g. Late Woodland) is conjectural, at the time of European settlement, portions of the coastal region (e.g. Martha's Vineyard, Nantucket, and Block Island) apparently supported among the highest population densities found in the Northeast [e.g. ten to twenty people per square kilometre (30-50 per square mile); Whitney, 1994]. In contrast, much lower population densities occurred on Cape Cod and Long Island. Thus, if Native American burning was responsible for the establishment of grasslands or other early successional habitats, we might expect that this would have been most important on the most densely populated islands or adjacent to Native settlements in more sparsely populated regions. The palaeoecological record provides partial support for this hypothesis. Some of the highest pre-European charcoal values from sediment cores in New England have been recorded from several ponds on Martha's Vineyard that also have high pre-European grass pollen percentages, suggesting that frequent fires may have helped to maintain areas of grassland or related habitats (Stevens, 1996). However, preEuropean grass pollen values in these cores remain relatively constant despite fluctuations in charcoal values (Foster et al., 2002). Pre-European grass pollen and charcoal values are substantially lower on Nantucket and Block Island despite high population densities (Dunwiddie, 1990a), and variation in charcoal values on Cape Cod apparently is not closely associated with Native settlement patterns (Parshall et al., 2003).

\section{The ethno-historical record}

Ethno-historical evidence is frequently cited in support of the notion of widespread grasslands and open vegetation during pre-European times (Russell, 1980; Cronon, 1983; Askins, 2000; see also Whitney, 1994). Accounts of early explorers, traders and settlers are interpreted as suggesting that: large open areas were common, especially in the coastal region (Little, 1981; Doolittle, 1992); shifting agriculture was widespread across southern New England and supported large Native American populations in semi-permanent villages (Cronon, 1983); and fire was routinely used to clear forests, improve habitat for hunting, and re-vitalize fallow areas for planting (Pyne, 1982). Interpretations of this literature suggest that through burning, rotational agriculture and related land use, Native Americans kept the landscape in a dynamic mosaic of forests of different age and structure, fields and fallows. Several authors have suggested that the dramatic decline of Native American populations in the sixteenth and seventeenth centuries resulted in a reduction or elimination of these land-use practices, leading to an increase in forest cover on formerly open areas:

"Before European settlement, this region [North-eastern US] was covered by a mosaic of open old-growth forests, shifting agriculture, and fire-maintained grasslands and savannahs. Following European contact, disease decimated
Native American populations, and much of the unsettled interior became wooded." Droge (1998).

The concept of pre-European New England as a humanized landscape strongly shaped by the interaction of natural and cultural processes represents part of a growing recognition of the influence of indigenous populations on the environment (cf. Butzer, 1992; Gomez-Pompa \& Kaus, 1992; Mann, 2002), which, in the north-eastern US, builds on earlier work (e.g. Bromley, 1935; Day, 1953; Niering, 1981). Perhaps the most influential thinking on this subject with regards to ecological interpretation and conservation activity in New England comes from historians and archaeologists including Cronon (1983), Pyne (1982) and Denevan (1992).

"Selective Indian burning thus promoted the mosaic quality of New England ecosystems, creating forests in many different states of ecological succession." "When Verrazano found twenty-five to thirty leagues of treeless land in Narragansett Bay, or Higginson spoke of thousands of acres in a similar state near Boston, they were observing the effects of agricultural Indians returning to fixed village sites and so consuming their forest energy supply." Cronon (1983).

"[In the Northeast, Midwest and Southeast, Native American] agricultural activity and burning had converted much of the forest into successional (fallow) growth and into semi-permanent grassy openings (meadows, barrens, plains, savannas and prairies)." Denevan (1992).

"There was little in the [North-eastern] forest to attract Indians, and they succeeded wherever possible in replacing forests with a mosaic of sites more to their liking... In many cases the combination of clearing and fires stripped off the forests altogether. 'Barrens', 'clearings' and 'deserts' were among the most common sights reported by early explorers. Undoubtedly, Indians maintained these deliberately as hunting grounds. Many of the clearings probably represented abandoned agricultural fields subsequently sustained as grasslands by annual broadcast burning. Whatever their origin, they were common at the time of discovery and were among the chief victims of settlement."

"Not all of the Northeast was converted to 'desert' or savannah. The upper mountains, the river bottoms, the swampy lowlands, and the denser boreal forests were more or less spared annual firings... Lacking domestic livestock, Indians depended on wildlife for meat, and these anthropogenic fire plains were their pastures. Ironically, many of the forests that occupied the great pine and oak belt of southern New England and across the Appalachians were a byproduct of European settlement...suppression of Indian fire practices made possible the accidental and deliberate reforestation of the Northeast. Not only was there frequently no virgin forest to clear, but the forest that was cleared was often itself a product of the act of settlement." Pyne (1982).

Several authors have evaluated the original sources supporting these interpretations, noting inherent difficulties of interpretation stemming from the fact that early historical descriptions of New England were written by individuals with varied personal knowledge of the landscape, describe limited areas, and cover more than a 200-year period of exploration and settlement (e.g. Russell, 1983; Whitney, 
1994). In addition, early writers often wrote from promotional or self-serving perspectives and may have focused on local and potentially uncommon phenomena (Day, 1953; Cronon, 1983; Russell, 1983; Patterson \& Sassaman, 1988; Whitney, 1994; Bragdon, 1996).

Based on a review of sources that cite early ethno-historical descriptions, we have compiled many of the primary references that address the nature of the early historical (primarily pre-eighteenth century) landscape for the coastal region or that describe Native American agriculture, fire and land-use practices (Fig. 3; see Appendix 1). Although a more thorough search of primary sources would undoubtedly yield numerous additional descriptions that are relevant, several important observations emerge from our review of those references that have been cited in interpretations of landscape history:

1. Very few early historical references clearly describe extensive upland grasslands. However, seventeenth century sources suggest that such grasslands occurred at Hempstead Plains on Long Island, New York [Denton (1670) in Neidich, 1980; Allen, 1997]. Early accounts also suggest the possible occurrence of smaller grasslands at Easthampton (Montauk), Long Island, along the coast of Martha's Vineyard or nearby islands (Brereton 1602), and perhaps in several additional locations along the coast of southern New England (Verrazano, 1524; Wood, 1634; Whitney, 1994).

2. Several early historical sources describe 'cleared' or 'open' land; most such references apparently refer to Native American agricultural fields or fallow lands, which were frequently noted by early European visitors to the coast.

3. Thick, shrubby vegetation apparently occurred along some portions of the shoreline (e.g. Cape Cod and Martha's Vineyard; Archer (1602); J. Smith [1614 (1905) in Holmes et al., 1997] and on some inland areas of the Great Plain on Martha's Vineyard (e.g. the 'Shrubed plain'; Banks, 1911) in the seventeenth century. Similar vegetation may have also occurred in the Connecticut Valley and other inland areas described as 'barrens' or 'barren pine plains'.

4. We found no early historical references to 'heathlands' or 'moors' in the region. Winne (1997) cites late eighteenth century descriptions of an extensive 'barrens' with low heath vegetation in eastern Maine that had burned.

5. Numerous references document the widespread occurrence of forests throughout New England, including the coastal region.

6. Fire was commonly used by Native Americans in the coastal region. Most early references to Native American fires refer to burning of forests or woodlands (rather than grasslands, heathlands or shrublands) in the vicinity of Native American settlements. Numerous references suggest that Native American burning resulted in reduced 'underwoods' in the forest, and that the resulting woodlands were 'open', with a low density of trees and abundant grass or weeds.
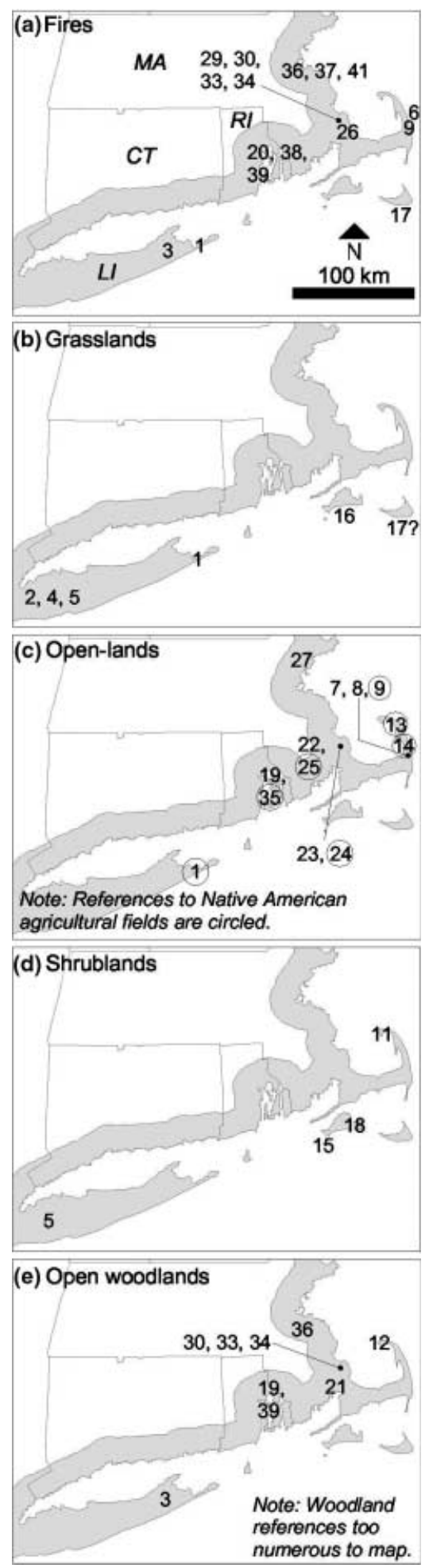

Figure 3 Early historical references to fire or vegetation in coastal New England and New York. Only references within $20 \mathrm{~km}$ of the shore (grey shading) are included. See Appendix 1 for numbered references. 


\section{Biological evidence for native open-land vegetation}

Several aspects of species autecology and distribution have been interpreted to suggest that grassland, savanna, shrubland or related non-forested habitats were widespread in the pre-European landscape. The decline in recent decades of numerous species that are dependent on open habitats relative to their historical abundance has been proposed as evidence that these habitats were common prehistorically (Dirig, 1994; Kurczewski, 1998). Similarly, the discontinuous or disjunct distribution of some species has been interpreted as suggesting that open habitats and associated species distributions were formerly more contiguous, and that current distribution patterns may reflect dramatic reductions in the extent of these habitats as a result of long-term climate change, fire suppression, land development or other causes (Campbell et al., 1990; Goldstein, 1997; Kurczewski, 1998). Such reductions in available habitat and in population levels may have reduced the probability of dispersal among increasingly isolated occurrences, further contributing to decline in characteristic species, particularly those that are poor dispersers (Givnish et al., 1988; Campbell et al., 1990). In addition, the occurrence of several open-land taxa that are endemic to the Northeast and the dependence of some native species on open vegetation structure or on host species characteristic of non-forested habitats suggests that this vegetation may have a long-standing (i.e. evolutionary) history in north-eastern North America (Schweitzer \& Rawinski, 1987; Dirig, 1990; Askins, 1997, 2000). Similarly, the ability of many open-land species to tolerate fire or to successfully reproduce and establish after fire (e.g. Cryan, 1985; Dirig, 1990; Dunwiddie, 1990b; Vickery et al., 1996; Vickery \& Dunwiddie, 1997; Vickery, 2002) suggests that these species are 'fire-adapted' and that fire has long influenced the occurrence and distribution of these habitats.

In contrast to the above interpretations, several authors have emphasized the need for caution in interpreting landscape history based on current species distributions and population characteristics. Limited understanding of the biology, distribution, dispersal abilities and habitat preferences of many taxa may confound interpretations of landscape history; for instance, Goldstein (1997) observed that many lepidopteran species that are thought to be grassland indicators are actually more common in pine-oak barrens than in grasslands on Martha's Vineyard, and several lepidopteran species that are thought to prefer open shrublands may also commonly occur in woodlands (M. Mello and T. Simmons, pers. comm.) In some instances, the abundance or host-specificity of insects may also undergo rapid changes in response to changing vegetation structure or composition (Singer et al., 1993). The host- and habitat-specificity of some lichen species associated with pine barrens may also be considerably broader than previously recognized (Dirig, 1990), and a few grassland bird species are known to have become established in the Northeast only during the historical period (Askins, 1997, 2000; Norment 2002). Mehrhoff (1997) notes that although 'prairie elements' occur in the flora of New England, this should not be interpreted as suggesting that the region formerly supported extensive prairie communities. Palaeoecological and historical analyses document the establishment or dramatic expansion of several grasslands, heathlands or barrens only in the past few centuries (Patterson \& Backman, 1988b; Dunwiddie, 1989, 1990a; Kurczewski, 1999; Kurczewski \& Boyle, 2000; E.W.B. Russell, unpublished manuscript), although it is likely that many of the uncommon plant species that are characteristic of these habitats occurred in the region prior to European settlement (Dunwiddie et al., 1996).

It is instructive to consider the example of the Heath Hen (Tympanuchus cupido cupido), a species whose former distribution has been interpreted as documenting the abundance of grasslands and other non-forested communities prior to European settlement (Askins, 1997, 2000). This subspecies of the prairie chicken formerly occurred from Massachusetts to Maryland, perhaps extending north to Maine and south to Virginia or the Carolinas (Gross, 1928; Askins, 1997). Although its occurrence in New England in the early historical period is well-documented (e.g. Wood, 1634), the Heath Hen declined across its range through the nineteenth century, partly in response to heavy hunting pressure, and ultimately became extinct in 1932 (Gross, 1928). Attempts at protection and restoration of heath hen in the early twentieth century prompted considerable research and the establishment of a state Heath Hen Reservation on Martha's Vineyard. The species' last population collapsed on what has become the Manuel F. Correllus State Forest following continued hunting, harsh winters, intense wildfire, and depredation by goshawks and feral cats (Gross, 1928; Foster \& Motzkin, 1999). Although the heath hen is frequently cited as evidence of the widespread occurrence of grasslands and scrublands in the pre-European landscape (Jones, 1995; Askins, 1997, 2000), most historical descriptions note that the primary habitats for this species were brushy plains or woodlands (see References cited in Gross, 1928) rather than grasslands, and considerable uncertainty remains as to the pre-European distribution and abundance of this species (Gross, 1928; Norment 2002).

\section{Field evidence for native grasslands}

Site-based evidence, including soil morphology, has occasionally been interpreted as indicating the long-term presence of open-land habitats in coastal New England. In his classic description of the North Haven and Wallingford, Connecticut sand plains, Olmsted (1937) interpreted the area as having supported persistent native grassland prior to European colonization, based on his interpretation of soil profiles. In areas that Olmsted interpreted as undisturbed by human activity, he characterized the typical profile as having developed under 'a persistent grassland cover prior to white colonization.' Specifically, the profile included a $20-\mathrm{cm}$ thick dark brown A horizon that terminated in a distinct lower boundary. Olmsted identified this as an analogue of true prairie soils, in which a deep A horizon develops from the decomposition of grass roots over millennia. 
Although Olmsted recognized that the sand plains had been largely cultivated for agriculture over previous centuries, he failed to recognize that the so-called 'prairie' soil profiles were apparently deep plow (Ap) horizons that developed historically through repeated plowing and harrowing of crop fields. Recent work throughout the Connecticut Valley north of Olmsted's sites confirms that such profiles predominate on similar sand plains today (Motzkin et al., 1996, 1999). These profiles persist for more than a century after the last agricultural activity, even on sites that appear quite natural. The profiles have very abrupt boundaries at $15-25 \mathrm{~cm}$ depth from brown A to light B horizons, and are thereby distinguished from the more gradual changes observed in true prairie soils. Plow horizons or other disturbed soils have also recently been documented from most modern grasslands and heathlands in the coastal region (Fig. 4), although many scrub oak shrublands lack such disturbed soil profiles.

\section{The historical period: expansion and decline of open-land habitats}

Historical and palaeoecological reconstructions document the dramatic landscape changes that resulted from European settlement. Across New England, European settlers embarked on a broad-scale transformation of the landscape, clearing upland forests to create an agrarian landscape by applying technology that was unavailable to Native Americans in unparalleled intensity (Russell, 1982; Foster, 1993;
Whitney, 1994). Fire, plowing or harrowing, and widespread grazing by domestic livestock resulted in a dramatic reduction in forests and the development of agrarian landscapes in which hayfields, pastures and cultivated fields predominated, and remaining woodlands were often grazed and intensively cut for fuel and lumber (Foster, 1999; Foster \& O'Keefe 2000; Eberhardt et al., 2003).

In much of the coastal region, deforestation and overgrazing led to rapid depletion of wood supplies through the seventeenth and eighteenth centuries; as a result, peat was mined for fuel in some areas and timber was imported from the mainland (McCaffrey, 1973; Banks, 1911; Dunwiddie, 1989; Friedman, 1993). Coincident with widespread forest clearance, grasslands and other open habitats expanded dramatically. This landscape transformation is well-documented in palaeo-reconstructions from the region, with a rapid increase of pollen from agricultural indicators, and grass pollen values that greatly exceeded those that were observed for the pre-European period (Fig. 2). Sheep grazing was particularly important on the coastal islands and the number of sheep rose rapidly, reaching c. 15,00020,000 on Martha's Vineyard by the late eighteenth century, with a similar number on Nantucket (Fig. 5). By the mid-nineteenth century, the coastal region supported extensive open habitats, although the distribution of these agricultural lands varied substantially across the region. Whereas Nantucket, Block Island, and some of the Elizabeth Islands were almost completely deforested (Hall et al.,

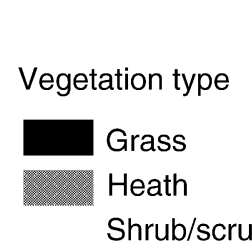

Soil disturbance

$\odot$ Disturbed or cultivated

$\otimes$ Not cultivated or disturbed

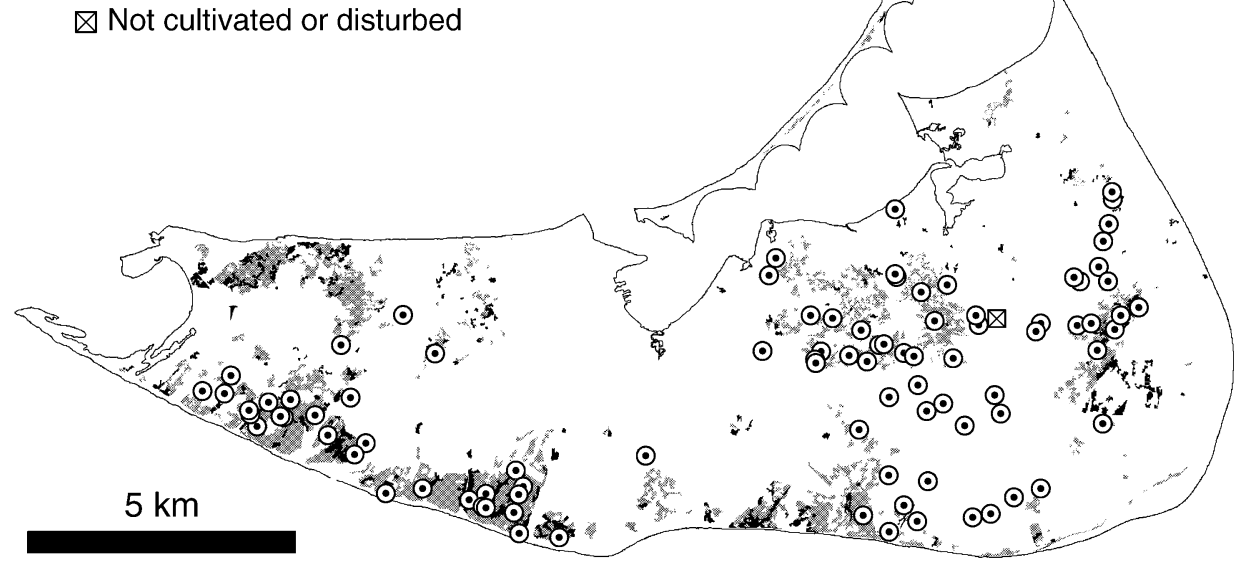

Figure 4 Map of the island of Nantucket indicating modern vegetation and the distribution of disturbed vs. undisturbed soil profiles in ninetyfive sample plots (HF unpublished data). Nearly all the extensive grasslands, heathlands and shrublands on the Island were formerly plowed, harrowed or otherwise disturbed, although plow horizons are frequently shallower than those found on inland sand plains. 
2002; United States Coast \& Geodetic Survey (USCGS)1836-1880), pasture and tilled fields on Martha's Vineyard were concentrated around the perimeter of the Island, and extensive woodlands and shrublands persisted in the centre of the Great Plain of Martha's Vineyard (Foster \& Motzkin, 1999), on inner Cape Cod (Hall et al., 2002), and in central Long Island (USCGS, 1836-1880; Allen, 1997).

Widespread abandonment of grazing and other farming practices occurred during the nineteenth century, although the timing varied across the region (Fig. 5). Following cessation of agriculture, dramatic shifts occurred in the species composition and structure of former agricultural lands (Jenkins, 1982; Harper, 1995; Dunwiddie, 1997). Although the composition of fields and pastures during and soon after the agricultural period was undoubtedly quite varied, late 19th and early twentieth century photographs from across the coastal region document the abundance of sparse, short stature grasslands with numerous flowering herbs and scattered low shrubs (Dunwiddie, 1992, 1994; Dunwiddie \& Adams, 1995; D. Brown \& C. Brown, unpublished). On heavily disturbed sites with exposed sand, heathlands with abundant low shrubs (e.g. Arctostaphylos uva-ursi, Corema conradii, Hudsonia ericoides) became increasingly dominant over time. Through the twentieth century, both heathlands and grasslands experienced widespread encroachment by taller woody vegetation, and a gradual development of successional woodlands. For instance, by 1985, only 271 ha of heathlands remained on Cape Cod National Seashore, representing a 63\% decrease from 1962 (Carlson et al., 1991). Although natural reforestation accounts for much of the increase in woodlands over the past century and a half throughout the coastal region, extensive planting of both native and non-native trees also contributed to the increase in woodlands (e.g. Bowditch, 1878; Baldwin, 1928; Rice, 1946; McCaffrey, 1973; Foster \& Motzkin, 1999). Currently, only small portions of the study region remain in open grassland or heathland (Dunwiddie et al., 1996), nearly all of which show clear field evidence of former agricultural use or other severe disturbance (Fig. 4). Scrub oak thickets and other tall shrublands remain common in some portions of the region, both on areas that were never cleared for agriculture (e.g. central portions of the Great Plain on Martha's Vineyard) and increasingly on areas that previously supported heathlands or grasslands (e.g. Middle Moors of Nantucket).

Coincident with increased establishment of woody vegetation on former agricultural lands since the mid-nineteenth century, a dramatic change has occurred in fire regimes. In some portions of the coastal region, fires were very frequent in the second half of the nineteenth and early twentieth centuries, especially on areas such as the central portion of the Great Plain on Martha's Vineyard that were never cleared for agriculture and that supported extensive thickets of scrub oak and short stature trees (Foster \& Motzkin, 1999). Improved fire detection and suppression during the 20th century have substantially reduced the importance of wildfires across much of the region (Dunwiddie \& Adams,

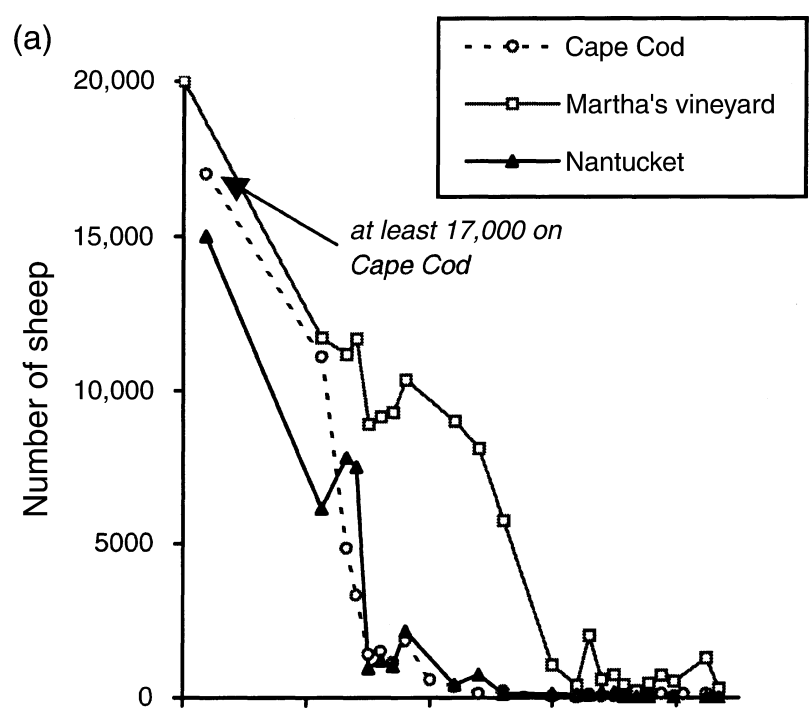

(b)

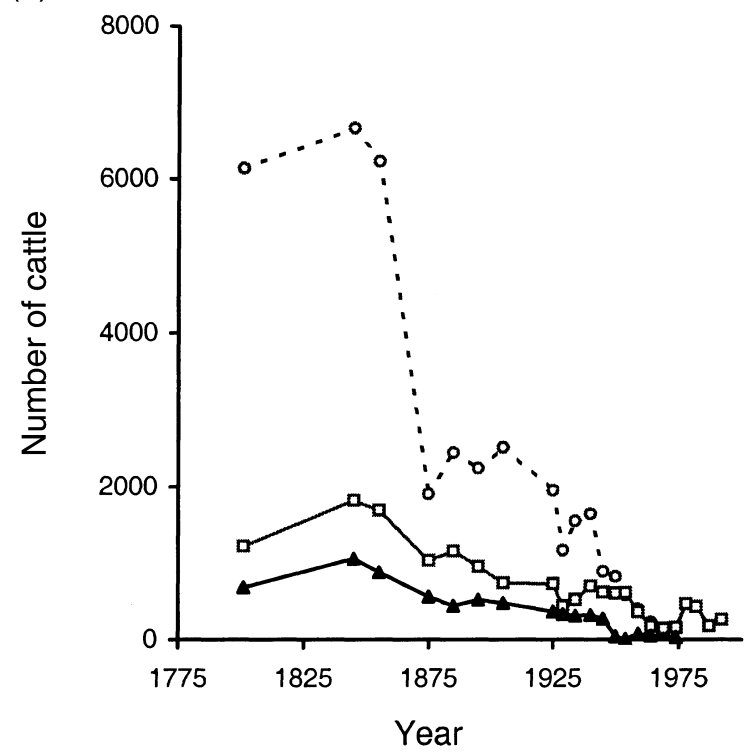

Figure 5 Historical changes in the abundance of sheep and cattle on Cape Cod, Martha's Vineyard, and Nantucket, Massachusetts. Data are from Freeman (1807), Massachusetts tax valuations (1801 and 1845-1905), and the US federal census (1905-present).

Note: Altpeter (1937) reported 7000-10,000 sheep on Cape Cod in 1660.

1995; although see A.G. Windish, unpublished), and have allowed for a substantial increase in the height of woodlands and shrublands.

\section{DISCUSSION}

\section{Interpreting the pre-European landscape}

The palaeoecological and prehistoric archaeological records suggest interpretations of the pre-European landscape that 
differ substantially from interpretations suggested by early historical descriptions of the coastal region and its inhabitants. Available palaeoecological reconstructions document the widespread importance of woody vegetation prior to European settlement, and, with the exception of some portions of the Great Plain on Martha's Vineyard, provide little evidence for the occurrence of grasslands or heathlands in the centuries prior to European arrival (Dunwiddie, 1990a; Stevens, 1996; Parshall et al., 2003). However, the existing palaeoecological record is not useful in determining the prehistoric occurrence and distribution of small grasslands or heathlands or in clarifying the importance of upland shrublands vs. woodlands. In particular, the fossil pollen of characteristic shrubland species (e.g. Quercus ilicifolia) cannot be distinguished from that of tree oaks, and characteristic ericaceous species occur commonly in woodlands, shrublands and heathlands.

In the pre-European period, fire was apparently common, as evidenced by relatively high fossil charcoal values, and it is likely that many fires resulted from Native American ignitions. Although archaeological reconstructions suggest that Native Americans in the region were not sedentary agriculturalists, Native populations undoubtedly altered the vegetation near settlements and may have had substantial influence in portions of the region with particularly high population densities. The incongruity between interpretations of Native American settlement patterns that are based on historical sources vs. prehistorical archaeological studies appears to result, at least in part, from real temporal differences. The social and economic structure of Middle and Late Woodland Indians were probably decidedly different than those recorded by observers in the seventeenth century and later (Chilton, 1999, 2001; Tveskov, 1992; Mulholland et al., 1998). This disparity apparently results from the rapid transformations that occurred in Native societies as a consequence of early European contact in the sixteenth century (Bragdon, 1996; Vaughan, 1979; Mulholland et al., 1998). Exposure to Europeans initiated social transformations, intertribal hostilities, diseases, and economic change that precipitated rapid and dramatic shifts in geographical distribution and land-use activity of Native Americans in the region (Ceci, 1977; Bragdon, 1996). Therefore, early ethno-historical descriptions, even if accurate, may record Native settlement and land-use practices that may not be representative of long-standing conditions (cf. Cronon, 1983; Bragdon, 1996). For example, some archaeologists have suggested that the concentration of Native Americans into coastal settlements in the early historical period may have been largely a reaction to increased trade opportunities with Europeans (Ceci, 1977). Similarly, intensive utilization of corn may have developed rapidly after European contact (Chilton, 1999) out of the necessity of feeding concentrated populations and the opportunity to produce a useful trade item. Rapid cultural changes after contact and the late arrival of corn to New England (c. 1100 AD) suggest that the village and agriculturally based cultures described by early writers may have been a relatively recent lifestyle, rather than a long-standing tradition (Ceci, 1977;
McBride, 1990; Bendremer, 1993; Bernstein, 1993; Chilton, 2001).

We propose that archaeological, palaeoecological, historical and modern field data indicate the need to re-evaluate the notion that coastal grasslands, heathlands, and related communities are long-standing and well-integrated assemblages of plants and animals. Available palaeoecological data suggest that in the centuries prior to European settlement, open upland habitats were uncommon in the coastal region and were probably largely restricted to sites subjected to chronic and intense disturbance (Dunwiddie, 1990a). Although we find no evidence for the occurrence of extensive pre-European heathlands comparable with historical ones, related vegetation undoubtedly occurred on dunes, areas of storm overwash and other heavily disturbed sites. Similarly, with the exception of the Hempstead Plains on Long Island and perhaps a few additional areas (e.g. Montauk, NY and portions of Martha's Vineyard), upland grasslands were apparently absent or uncommon through most of the coastal region. The lack of palaeoecological evidence for extensive pre-European grasslands or heathlands in the region is consistent with the lack of natural disturbances capable of generating and maintaining such habitats. Similarly, it is unclear why Native Americans in the coastal region would have intentionally attempted to create extensive grasslands or heathlands, or whether their land-use practices would have unintentionally generated such communities. Although early historical records document the frequent use of fire by Native Americans, most references describe burning of woodlands in the vicinity of Native villages (Whitney, 1994).

In contrast to upland grasslands and heathlands, the palaeoecological record provides little insight into the structure of woodlands in the pre-European period, or the relative abundance of shrublands, young woodlands and mature forests. However, palaeoecological data document that fire was common in the coastal region in the pre-European period, which is consistent with the occurrence of large Native populations that apparently used fire frequently. The impact of Native burning was probably greatest near settlements or in portions of the region with particularly high population densities. In such areas, fallows and woodlands with reduced 'underwood' were frequently noted by early settlers, indicating substantial local impact by Native Americans on forest composition and structure. In addition, early references to dense shrubby vegetation suggest that short stature woodlands or shrublands occurred along the shoreline as well as in some interior portions of the coastal region. We suspect that shrublands and woodlands were substantially more common than extensive grasslands or heathlands across the coastal region in the pre-European period.

\section{Open lands in the historical period}

Regardless of the distribution of open habitats prior to European arrival, there is strong evidence that these habitats increased dramatically during the historical period, and nearly all sites supporting modern grasslands and heathlands 
show clear evidence of having been substantially altered by historical land use. Across New England, it has been estimated that up to 6 million acres of grasslands existed in the mid nineteenth century, habitat that was widely utilized by grassland birds and invertebrates (Sharpe, 1994). Although less widely appreciated, the abundance of open-land plant species increased as well. In fact, many coastal plant species that are rare or uncommon today were apparently most abundant in the few decades after abandonment of pastures and fields (Jenkins, 1982; Dunwiddie, 1997). Similarly, the composition and structure of modern grasslands and heathlands have developed only after many decades of release from severe historical disturbance, including plowing, harrowing, grazing and burning.

The presence of plow horizons or other disturbed soil profiles in most grasslands and heathlands across the region combined with widespread and intensive grazing for c. 200 years indicate the historical and cultural origins of these communities. Although it is difficult to fully assess the intensity of historical disturbances to these sites, some insight may be gained from comparison with more recent disturbances that have generated similar vegetation. Across the coastal region, heathland or grassland vegetation became established in the twentieth century on some former military bases, powerlines, road edges and firebreaks after cessation of intensive physical disturbance, often including complete removal of the organic layer and mechanical disturbance of the underlying mineral soil. Heath vegetation has also become established on some areas of overwash from hurricanes or other severe storms. We suggest that plowing, harrowing and intensive grazing in the historical period were comparably severe, although substantially more extensive, disturbances that gave rise to widespread grasslands and heathlands over the past century and a half. Thus, it appears that a range of severe and primarily anthropogenic disturbances may generate coastal grasslands and heathlands, and essentially all extant examples of these communities show clear evidence of such historical disturbances.

If modern grasslands and heathlands are largely the result of historical anthropogenic disturbance, where did the species that are characteristic of these communities occur in the pre-European landscape? We suspect that many of these species were uncommon prior to European land clearing and were largely restricted to chronically or intensively disturbed sites. Rather than occurring in extensive communities comparable with modern ones, some species may have occurred in burned or otherwise disturbed sites or on exposed habitats along the coastal fringe that are regularly subjected to high winds and salt spray (Dunwiddie \& Caljouw, 1990; Tiffney, 1997; Dunwiddie, 1998). The open woodlands that resulted from Native American burning also may have supported some 'grassland' or 'heathland' species, although the composition, structure, and extent of these areas are completely unknown. A few mid-western bird species are known to have extended their ranges into the Northeast during the historical period (Askins, 2000; Norment, 2002); however, we suspect that many of the uncommon plant taxa may have been present in the region before European settlement, though perhaps on different sites and in differing abundances and assemblages than the ones in which they occur today.

The observation that species characteristic of open habitats expanded widely during the agricultural period and have subsequently declined as these disturbances have decreased (Jenkins, 1982; Harper, 1995; Dunwiddie, 1997; Norment, 2002) suggests that modern assemblages developed largely during the historical period and may have little long-term integrity. In many ways, this interpretation parallels the history and origin of field plants in north-eastern North America advanced by Marks (1983). Consistent with this interpretation is the suggestion that the decline of several rare grassland plant species may result from their inability to reproduce successfully in the absence of patches of bare mineral soil which were formerly created by grazing (Dunwiddie \& Sferra, 1991; Dunwiddie, 1997) or fire (Dunwiddie, 1990b). Although many coastal grasslands and heathlands have been rapidly overgrown by tall shrubs and trees, extremely windy conditions, salt spray, the absence of seed sources, and occasional fires and other disturbances have slowed the process, especially in exposed areas near the shore (Boyce, 1954; Dunwiddie, 1989). As a result, although early successional habitats have decreased substantially in the past century, palaeoecological data from across the coastal region suggest that grasslands and other open habitats remain more extensive than in the pre-European period (Fig. 2; Stevens, 1996; Foster et al., 2002; Parshall et al., 2003).

\section{Conservation implications of the history of open-land habitats}

Although ecologists, conservationists and naturalists have long speculated on the history of coastal grasslands, heathlands, shrublands and woodlands, considerable uncertainty remains as to whether early successional communities comparable with modern ones occurred prior to European arrival and the extent to which Native American burning or other processes may have contributed to their occurrence. Similarly, the pre- and early-historical distribution and abundance of uncommon plant and animal species that are characteristic of open habitats today are almost completely unknown. It is, however, clear that the modern distribution, composition and dynamics of these habitats result from the dramatic and widespread alteration of the coastal landscape during the historical period and that modern assemblages are not likely to closely resemble those that may have occurred prior to European arrival. As a result, an understanding of the historical disturbances that gave rise to modern assemblages must be incorporated into conservation and management of these communities.

In evaluating conservation and management approaches, it is necessary to distinguish between coastal grasslands, heathlands and scrub oak-dominated shrublands, for these have differing histories, plant and animal assemblages, and conservation values. In particular, the modern distributions of rare plant and animal species differ substantially among these early successional habitats. Many upland plants and 
birds that are regionally rare occur in coastal grasslands, heathlands or other disturbed habitats (e.g. firebreaks, former military bases, etc.), whereas uncommon invertebrate species are primarily associated with shrublands or woodlands (Goldstein, 1997). Most sites currently supporting heathlands underwent intensive and often degrading land use during the historical period that generated a suite of novel habitats and vegetation types; in some areas, overgrazing led to the exposure of topsoil, wind erosion and even dune development, with considerable re-distribution of soils (McCaffrey, 1973). Nutrients were also re-distributed locally and removed via cropping. The resulting landscape, which contemporary observers described as degraded, barren, rutted, eroded and wasteland (Thoreau, 1857), supports the heathlands and related early successional habitats that we value today. Tiffney (1997) has underscored similarities between North American and European heathlands and the critical role that nutrient depletion plays in their development and maintenance. As suggested by many European ecologists (cf. Gimingham, 1972), grazing, harvesting, litter removal and fire are critical components of traditional heathland management because they result in decreased site fertility. Under conditions of high nutrient availability, competitive species become established that may replace the smaller heath species. Consequently, one goal of heath management is to reinforce the poor quality of site conditions, thereby minimizing productivity and competition (Sutherland \& Hill, 1995). Ironically, although heathlands provide important conservation and aesthetic values, establishment and maintenance of such communities on sites other than exposed coastal locations may require severe disturbances (e.g. over-grazing or mechanical soil scarification; Odgaard \& Rasmussen, 2000) with undesirable environmental impacts.

In contrast, many woodlands and scrub oak-dominated shrublands in the region show no evidence of anthropogenic soil disturbance. Although most of these communities have been cut or burned repeatedly through the historical period, we suspect that these disturbances have had greater effects on vegetation structure and species abundance than on species composition. This hypothesis has important implications for interpreting the abundance of rare species associated with coastal woodlands and shrublands. A high percentage of the rare invertebrate species in the region are associated with one of only a few common woody host species (especially Quercus ilicifolia, Vaccinium angustifolium, Pinus rigida; D. Wagner pers. comm.) each of which occurs in a range of wooded habitats including woodlands, barrens and shrublands. Although many uncommon species are currently found in scrub oak 'frost bottoms' (Goldstein, 1997), the long-term history of these habitats is unclear and, in some instances, their structure apparently developed as a result of historical cutting and burning (Motzkin et al., 2002). This suggests that even on sites that were less disturbed by historical land use than grasslands and heathlands, the local abundance and distribution of rare species today may be substantially altered from that which occurred in the pre- or early-historical periods.

\section{Managing cultural landscapes}

Recognition of the historical and often agricultural origins of many grasslands and heathlands in the coastal region suggests that in order to maintain and restore these communities, the use of traditional (agricultural) management regimes may be most effective. To date, conservation agencies have emphasized the use of prescribed fire and, to a lesser extent, mowing to maintain these open lands, with little research or management focus on the potential use of grazing or other traditional agricultural practices. Results from nearly 20 years of prescribed fire and mowing treatments in grasslands in the region indicate mixed effectiveness at preventing succession to woody vegetation and maintaining uncommon species (Niering \& Dreyer, 1989; Dunwiddie \& Caljouw, 1990; Dunwiddie, 1990b, 1991, 1998; Dunwiddie et al., 1997; Rudnicky et al., 1997; TNC, unpublished manuscript; Vickery, 2002). These studies underscore the importance of severe disturbances for maintaining grassland assemblages; spring burns have typically been less effective at slowing woody succession, increasing species richness of herbs and forbs, and promoting rare species than summer burns or mowing (Dunwiddie, 1998). In particular, summer burns are more effective at exposing patches of mineral soil necessary for several rare grassland plant and bird species. However, despite the greater effectiveness of summer burns, it is unlikely that prescribed summer burns can be widely implemented because of logistical problems, including increased smoke production, difficulty of extinguishing duff fires, and potential conflicts with tourists during the summer season (Dunwiddie, 1998).

Although many agricultural lands were burned historically as part of complex management regimes, plowing, harrowing, and intensive grazing were likely to have been primary disturbances that resulted in long-lasting impacts on vegetation composition and structure. Cessation of these traditional practices allowed precisely the changes that seventeenth-nineteenth century farmers were attempting to prevent: the widespread establishment and growth of woody species (Budd, 2000). The agricultural history of the region suggests that intensive grazing should be seriously evaluated as a management alternative; in particular, it should be recognized that grazing may achieve many ecological objectives that are similar to prescribed summer burns. Importantly, although experimental data are generally lacking, some rare species (e.g. Helianthemum dumosum) that successfully reproduce after prescribed fire are also characteristic of abandoned pastures that have not burned for many decades (Dunwiddie, 1990b, 1997). The suggestion that sheep grazing and other traditional agricultural practices may be useful in maintaining or restoring coastal grassland and heathland assemblages parallels the interpretations of many European conservationists, including Sutherland \& Hill (1995) who state that 'the failure to maintain continuity of management within semi-natural habitat is at the heart of most conservation problems... traditional management should be maintained wherever possible.' Recognizing the role of historical agriculture in generating early successional 
habitats, several conservation agencies in the coastal region have recently begun experimenting with the use of sheep grazing, in addition to mowing and burning, for management of open lands (Anonymous, 2001; Capece, 2001).

\section{Re-examining the objectives of land conservation and management}

Given the recent emphasis, particularly in the US, on the maintenance and restoration of natural processes and natural landscapes, the realization that many upland grasslands, heathlands and shrublands have clear cultural origins requires re-evaluation of conservation objectives for these habitats (Peterken, 1977; Birks, 1996; Norment, 2002). There are at least three motivations that have been presented in American and European conservation discussions for maintaining cultural landscapes: (1) cultural landscapes are aesthetically pleasing and historically valuable, and provide social and economic benefits through recreation and tourism (Norderhaug et al., 2000; OECD, 2001); (2) cultural and artificial habitats provide adequate substitutes for native habitats destroyed elsewhere in the historical range of target species (Norment, 2002); and (3) maintenance of all levels of existing biodiversity is an important priority (Lawton, 1997; Wilson, 2002).

The conservation of historical landscapes and associated assemblages for cultural and aesthetic values has become an important consideration in several European countries where the encultured nature of the landscape is perhaps more readily accepted than in North America and where historical tradition resonates strongly with a population that often shares a long cultural background. Across north-western Europe, many traditional landscapes have been lost at a rapid rate because of active land conversion, intensification of agriculture, and active or passive reforestation (Kaland, 1986; Lavers \& Haines-Young, 1993; Watkins, 1993; Sutherland \& Hill, 1995). These changes have wrought major impacts on the visual quality of the land as well as its habitat value (Robertson, 1990). In some regions, government programmes have been developed to support rural people pursuing traditional agricultural lifestyles or to train individuals to continue such practices in protected localities (Birks et al., 1988). For instance, in Norway, the maintenance of small-scale farming on steep fiordlands and montane sites is valued primarily as a means of maintaining long-standing cultural traditions. Support of similar activities in several European countries has been viewed as strengthening rural communities, benefiting the tourist industry, and providing ecological and conservation value (OECD, 2001). Similar arguments may well apply to the grasslands and heathlands of coastal New England. In addition, because many natural grasslands in North America have been converted to intensive agricultural use, numerous formerly common taxa have declined and may benefit from the refuge provided by highly artificial landscapes. Interjecting conservation-orientated management schemes into the maintenance of former agricultural lands as well as highly artificial landscapes such as landfills, airfields and military bases may result in substantial benefit to target species, and often requires only minimal adjustment of the seasonal timing and approach to routine management activities. Consequently, it is frequently possible to increase the conservation value of remaining cultural landscapes quite effectively.

\section{Increasing the historical and scientific basis for management}

The interpretation of the origin, dynamics and maintenance of early successional habitats that we present underscores the need to incorporate a rigorous historical and scientific framework into conservation and management activities. It is highly informative, if not essential, to evaluate the longterm dynamics of major species assemblages that are the target of conservation efforts and the factors controlling changes in vegetation structure and composition over time. Although tools and sources of information may vary, similar approaches are warranted regardless of whether the landscape is perceived as controlled by natural or cultural processes (Egan \& Howell, 2001). Thus, although there is a strong emphasis in American conservation on the identification of the natural range of variability in ecological systems as a basis for management (e.g. Landres et al., 1999), a similar emphasis on history is required for systems in which changing cultural practices have been important environmental drivers (cf. Swetnam et al., 1999). In many instances, the relative influence of natural vs. cultural processes may not be known prior to detailed study, as was the case for the grasslands and heathlands of coastal New England.

Once the historical underpinnings and ecological drivers of the conservation target are documented, it is essential that clear objectives and a framework for management are established, including specific statement of objectives, motivations, expectations and desired outcomes. Ultimately, selecting specific conservation objectives is not a scientific decision, but is based on often un-stated political, aesthetic and cultural values. Science may inform decision-making and may guide management once objectives are set, but selecting objectives is inherently subjective (Lawton, 1997; Foster \& Motzkin, 1998). Once objectives are established, a system of adaptive management should include: clearly stated objectives; an assessment of feasibility; a prescription for management based on identification of appropriate methods; a system of long-term monitoring including baseline data collection; application of management under an adaptive framework that allows for assessment and reevaluation; and a plan for revisiting methods and objectives (Sutherland \& Hill, 1995; Dunwiddie, 2001).

\section{Concluding thoughts}

Conservation and land management are challenging enterprises even in landscapes where natural processes have dominated for millennia. However, in most regions, human and natural processes have operated with changing intensities over time. Historical studies are useful in identifying the changing factors that have shaped landscapes over time and such studies frequently indicate that modern conditions developed as a result of prior disturbances (Foster et al., 
2003). Recognition of the cultural nature of many valued landscapes introduces complexities to conservation policy. Because of the lengthy and varied lags in response to historical impacts, the modern landscape is highly dynamic and management of cultural landscapes may require sustaining human activity that is considered to be outmoded, inefficient or environmentally unsound; or, it may make us seize on highly artificial alternatives to historical landscapes as habitats for species that are threatened. Alternatively, recognition of the cultural origins and highly dynamic nature of many assemblages may indicate the value of reducing active management on some sites, albeit with the recognition that dramatic changes in species composition and structure may occur.

The insights arising from historical perspectives force us to address fundamental questions. What landscapes do we value and why? Should we attempt to maintain cultural sites and assemblages? Are we seeking to maintain or re-create landscapes and assemblages from specific time periods? Once we have addressed these and related questions, we can return to historical information for further insights into management approaches with some expectation of success and some perspective on attending results. Thus, while we may open new policy and ethical discussions through these studies, we also learn much about ecological process and new options for management.

\section{ACKNOWLEDGMENTS}

We thank Brian Hall, John Burk, and Julie Hall for gathering historical data, and Dana MacDonald, Jon Harrod, Art Allen, and the coastal field crews for field data. Dave Orwig, Richard Cobb, and members of the Harvard Forest lab group provided useful comments, and Brian Hall developed the figures. Thanks to Peter Dunwiddie for comments on a previous draft of the manuscript, and to Andrea Stevens for permission to use her data. Funding for this study was provided by The Nature Conservancy's Ecological Research Program, Massachusetts Biodiversity Initiative Ecological Restoration Program, National Science Foundation, and Andrew Mellon Foundation. This paper is a contribution of the Harvard Forest Long Term Ecological Research Program.

\section{REFERENCES}

Allen, D.Y. (1997) Long Island maps and their makers. Amereon House, Mattituck, NY.

Altpeter, L.S. (1937) A history of the forests of Cape Cod. MS Thesis, Harvard University, Petersham, MA.

Anonymous (2001) Sheep power harnessed to control runaway vegetation on protected land. Natural New England, 5, 6-8.

Archer, G. [1602 (1983)] Gabriel Archer's account of Captain Bartholomew Gosnold's voyage to 'North Virginia' in 1602. The English New England voyages 1602-1608 (eds D.B. Quinn and A.M. Quinn), pp. 112-138. Hakluyt Society, London.

Askins, R.A. (1997) History of grasslands in the northeastern United States: implications for bird conservation. Grasslands of northeastern North America: ecology and conservation of native and agricultural landscapes (eds P.D. Vickery and P.W. Dunwiddie), pp. 119-136. Massachusetts Audubon Society, Lincoln, MA.

Askins, R.A. (2000) Restoring North America's birds. Yale University Press, New Haven, CT.

Backman, A.E. (1984) 1000-year record of fire-vegetation interactions in the northeastern United States. MS Thesis, University of Massachusetts, Amherst.

Baldwin, H.I. (1928) The trees of Nantucket: early records throw light on the much discussed question of whether there were ever forests on the Island. American Forests and Forest Life, 34, 664-665, 684.

Banks, C.E. (1911) (1966) The history of Martha's Vineyard, Dukes County, Massachusetts, 3 Volumes. Dukes County Historical Society, Edgartown.

Barbour, H., Simmons, T., Swain, P. \& Woolsey, H. (1998) Our irreplaceable heritage - protecting biodiversity in Massachusetts. Massachusetts Natural Heritage and Endangered Species Program and the Massachusetts Chapter of The Nature Conservancy, Boston, MA.

Beers, A. \& Davison, S. (1999) North Atlantic coast ecoregional conservation plan. The Nature Conservancy, Arlington, VA.

Bendremer, J.C.M. (1993) Late woodland settlement and subsistence in eastern Connecticut. PhD Dissertation, University of Connecticut, Storrs.

Bernabo, J.C. (1977) Sensing climatically and culturally enduced environmental change using palynological data. PhD Dissertation, Brown University, Providence, RI.

Bernstein, D.J. (1993) Prehistoric subsistence on the southern New England coast: the view from Narragansett Bay. Academic Press, San Diego.

Birks, H.J.B. (1996) Contributions of Quaternary palaeoecology to nature conservation. Journal of Vegetation Science, 7, 8998.

Birks, H.H., Birks, H.J.B., Kaland, P.E. \& Moe, D. (eds) (1988) The cultural landscape: past, present, and future. Cambridge University Press, Cambridge.

Bowditch, J.H. (1878) Forestry notes. Report of Secretary of Connecticut State Board of Agriculture, 1877-1878, 3-44.

Boyce, S.G. (1954) The salt spray community. Ecological Monographs, 24, 29-67.

Bragdon, K.J. (1996) Native people of southern New England 1500-1650. University of Oklahoma Press, London.

Brereton, J. (1602) (1983) A briefe and true relation of the discoverie of the north part of Virginia. The English New England voyages 1602-1608 (eds D.B. Quinn and A.M. Quinn), pp. 139-302. Hakluyt Society, London.

Bromley, S.W. (1935) The original forest types of southern New England. Ecological Monographs, 5, 61-89.

Budd, B. (2000) Cows and conservation. New source (Newsletter). Ecological Society of America, 71, 2.

Butzer, K.W. (ed.) (1992) The Americas before and after 1492: current geographical research. Annals of the Association of American Geographers, 82, 343-564.

Campbell, J.J.N., Taylor, D.D., Medley, M.E. \& Risk, A.C. (1990) Floristic and historical evidence of fire-maintained, grassy pine-oak barrens before settlement in southeastern Kentucky. Fire and the environment: ecological and cultural 
perspectives. Proceeding of an International Symposium (eds S.C. Novin and T.A. Walrop), pp. 359-375. US Department of Agriculture Southeastern Forest Experiment Station General Technical Report SE-69. Knoxville, Tennessee.

Capece, J. (2001) Land-use history of Cape Poge and Wasque. The Trustees of Reservations, Vineyard Haven, MA.

Carlson, C.C., Armelagos, G.J. \& Magennis, A.L. (1992) Impact of disease on precontact and early historic populations of New England and the Maritimes. Disease and Demography in the Americas (eds J.W. Verano and D.H. Ubelaker), pp. 141-153. Smithsonian Institution Press, Washington, DC.

Carlson, L., Babione, M., Godfrey, P.J. \& Fowler, A. (1991) Ecological survey of heathlands in Cape Cod National Seashore, MA. Botany Department, University of Massachusetts, Amherst.

Carroll, C.F. (1973) The timber economy of puritan New England. Brown University Press, Providence.

Ceci, L. (1977) The effect of European contact and trade on the settlement pattern of Indians in coastal New York, 15241665: the archaeological and documentary evidence. PhD Dissertation, City University of New York, New York.

Chilton, E.S. (1999) Mobile farmers of pre-contact southern New England: the archaeological and ethnohistoric evidence. Current Northeast Paleoethnobotany (ed. J.P. Hart), pp. 157176. New York State Museum Bulletin no. 494, Albany, NY.

Chilton, E.S. (2002) Towns They Have None: diverse subsistence and settlement strategies in native New England. Northeast subsistence settlement change: A.D. 700-A.D. 1300 (eds J. Hart and C. Reith). New York State Museum Bulletin, New York (in press).

Chilton, E.S. (2001) The archaeology and ethnohistory of the contact period in the northeastern United States. Reviews in Anthropology, 30, 55-78.

Cook, S.F. (1976) The Indian population of New England in the seventeenth century. Publications in Anthropology, 12, 1-91. University of California, Berkeley.

Cox, T.R., Maxwell, R.S., Thomas, P.D. \& Malone, J.J. (1985) This well-wooded land. University of Nebraska Press, Lincoln.

Cronon, W. (1983) Changes in the land - Indians, colonists, and the ecology of New England. Hill and Wang, New York.

Cryan, J.F. (1985) Retreat in the barrens. Defenders Jan/Feb, 18-29.

Day, G.M. (1953) The Indian as an ecological factor in the Northeastern forest. Ecology, 34, 329-346.

Denevan, W.M. (1992) The pristine myth: the landscape of the Americas in 1492. Annals of the Association of American Geographers, 82, 369-385.

Denton, D. (1670) (1966) A brief description of New York. March of America Facscimile series no. 26. University Microfilms, Ann Arbor, Michigan.

Dirig, R. (1990) Distributional and ecological notes on Hypocenomyce scalaris (Lecanorales, Lecideaceae) in eastern North America. Mycotaxon, 37, 441-462.

Dirig, R. (1994) Historical notes on Wild Lupine and the Karner Blue Butterfly at the Albany Pine Bush, New York. Karner Blue Butterfly - a symbol of a vanishing landscape (eds D.A. Andow, R.J. Baker and C.P. Lane), pp. 23-36. Miscellaneous Publication 84-1994, Minnesota Agricultural Experiment Station. University of Minnesota, St Paul.
Doolittle, W.E. (1992) Agriculture in North America on the eve of contact: a reassessment. Annals of the Association of American Geographers, 82, 386-401.

Droge, S. (1998) Birds and landscape changes in northeastern forests. Status and trends of the nation's biological resources (eds M.J. Mac, P. Opler, C. Haecker and P. Dorin), pp. 187189. US Department of the Interior, USGS, Washington, DC.

Dunford, F. \& O'Brien, G. (1997) Secrets in the sand: the archaeology of Cape Cod. Parnassus Imprints, Hyannis, Massachusetts.

Dunwiddie, P.W. (1989) Forest and heath: the shaping of the vegetation of Nantucket Island. Journal of Forest History, 33, 126-133.

Dunwiddie, P.W. (1990a) Postglacial vegetation history of coastal islands in southeastern New England. National Geographic Research, 6, 178-195.

Dunwiddie, P.W. (1990b) Rare plants in coastal heathlands: observations on Corema conradii (Empetraceae) and Helianthemum dumosum (Cistaceae). Rhodora, 92, 22-26.

Dunwiddie, P.W. (1991) Comparisons of above-ground arthropods in burned, mowed, and untreated sites in sandplain grasslands. American Midland Naturalist, 125, 206-212.

Dunwiddie, P.W. (1992) Changing landscapes. Nantucket Conservation Foundation, Nantucket Historical Association, Massachusetts Audubon Society, Reynolds DeWalt, New Bedford, MA.

Dunwiddie, P.W. (1994) Martha's Vineyard landscapes: the nature of change. The Vineyard Conservation Society and P. W. Dunwiddie, Edgartown, MA.

Dunwiddie, P.W. (1997) Long-term effects of sheep grazing on coastal sandplain vegetation. Natural Areas Journal, 17, 261264.

Dunwiddie, P.W. (1998) Ecological management of sandplain grasslands and coastal heathlands in southeastern Massachusetts. Tall Timbers Fire Ecology Conference Proceedings, 20, 83-93.

Dunwiddie, P.W. (2001) Using historical data in ecological restoration: a case study from Nantucket. The historical ecology handbook (eds D. Egan and E.A. Howell), pp. 367390. Island Press, Washington.

Dunwiddie, P.W. \& Adams, M. (1994) Landscape change on Martha's Vineyard and the Elizabeth Islands 1640-1993. The Nature Conservancy, Massachusetts Field Office, Boston, MA.

Dunwiddie, P.W. \& Adams, M. B. (1995) Fire suppression and landscape change on outer Cape Cod, 1600-1994. Nat'l Park Service Technical Report NPSNESO-RNRARTR96-08. Boston, MA.

Dunwiddie, P.W. \& Caljouw, C. (1990) Prescribed burning and mowing of coastal heathlands and grasslands in Massachusetts. Ecosystem management: rare species and significant habitats (eds R.S. Mitchell, C.J. Sheviak and D.J. Leopold), pp. 271-275. Proceedings of the 15 Annual Natural Areas Conference, New York State Museum, New York, Bulletin 471.

Dunwiddie, P.W., Patterson, W.A. III, Rudnicky, J.L. \& Zaremba, R.E. (1997) Vegetation management in coastal grasslands on Nantucket Island, Massachusetts: effects of burning and mowing from 1982 to 1993. Grasslands of northeastern North America: ecology and conservation of 
native and agricultural landscapes (eds P.D. Vickery and P.W. Dunwiddie), pp. 85-98. Massachusetts Audubon Society, Lincoln, MA.

Dunwiddie, P.W. \& Sferra, N. (1991) Loss of rare butterfly and plant species in coastal grasslands. Natural Areas Journal, 11, 119-120.

Dunwiddie, P.W., Zaremba, R.E. \& Harper, K.A. (1996) A classification of heathlands and sandplain grasslands in Massachusetts. Rhodora, 98, 117-145.

Eberhardt, R.W., Foster, D.R., Motzkin, G. \& Hall, B. (2003) Conservation of changing landscapes: vegetation and landuse history of Cape Cod National Seashore. Ecological Applications, in press.

Egan, D. \& Howell, E.A. (eds) (2001) The historical ecology handbook. Island Press, Washington.

Fletcher, P.C. \& Roffinoli, R.J. (1986) Soil survey of Dukes County, Massachusetts. US Department of Agriculture Soil Conservation Service, Washington, DC.

Foster, D.R. (1993) Land-use history and forest transformations in central New England. Humans as components of ecosystems (eds M.J. McDonnell and S.T.A. Pickett), pp. 91-110. Springer-Verlag, New York.

Foster, D.R. (1999) Thoreau's country - journey through a transformed landscape. Harvard University Press, Cambridge, MA.

Foster, D.R. \& Motzkin, G. (1998) Ecology and conservation in the cultural landscape of New England: lessons from nature's history. Northeastern Naturalist, 5, 111-126.

Foster, D.R. \& Motzkin, G. (1999) Historical influences on the landscape of Martha's Vineyard - perspectives on the management of Manuel F. Correllus State Forest. Harvard Forest Paper no. 23. Harvard Forest, Petersham, MA.

Foster, D.R., Hall, B., Barry, S., Clayden, S. \& Parshall, T. (2002) Cultural, environmental and historical controls of vegetation patterns and the modern conservation setting on the island of Martha's Vineyard, USA. Journal of Biogeography, 29, 1381-1400.

Foster, D.R., Swanson, F., Aber, J., Burke, I., Brokaw, N., Tilman, D. \& Knapp, A. (2003) The importance of land-use and its legacies to ecology and environmental management. Bioscience, in press.

Foster, D.R., Motzkin, G. \& Slater, B. (1998) Land-use history as long-term broad-scale disturbance: regional forest dynamics in central New England. Ecosystems, 1, 96-119.

Foster, D.R. \& O'Keefe, J.F. (2000) New England forests through time - insights from the Harvard Forest dioramas. Harvard Forest, Petersham, MA.

Freeman, J. (1807) A description of Duke's County. Collections of the Massachusetts Historical Society, Vol. 3. Second Series (1815), pp. 38-95. John Eliot, Boston.

Friedman, R.L. (1993) Governing the land: an environmental history of Cape Cod, Massachusetts 1600-1861. PhD Dissertation, Brandeis University, Waltham, MA.

Fuller, J., Foster, D.R., McLachlan, J. \& Drake, N. (1998) Impact of human activity on regional forest composition and dynamics in central New England. Ecosystems, 1, 76-95.

Gimingham, C.H. (1972) Ecology of heathlands. Chapman and Hall, London.

Givnish, T.J., Menges, E.S. \& Schweitzer, D.F. (1988) Minimum area requirements for the long-term conservation of the
Albany Pine Bush and Karner Blue Butterfly: an assessment. Malcolm Pirnie, Inc., Albany, NY.

Goldstein, P.Z. (1997) Lepidopteran assemblages and the management of sand plain communities on Martha's Vineyard, Massachusetts. Grasslands of northeastern North America: ecology and conservation of native and agricultural landscapes (eds P.D. Vickery and P.W. Dunwiddie), pp. 217236. Massachusetts Audubon Society, Lincoln, MA.

Gomez-Pompa, A. \& Kaus, A. (1992) Taming the wilderness myth. Bioscience, 42, 271-279.

Gross, A.O. (1928) The heath hen. Memoirs of the Boston Society of Natural History, Vol. 6, no. 4. Boston, MA.

Hall, B., Motzkin, G., Foster, D.R., Syfert, M. \& Burk, J. (2002) Three hundred years of forest and land-use change in Massachusetts, USA. Journal of Biogeography, 29, 1319-1335.

Harper, K.A. (1995) Effect of expanding clones of Gaylussacia baccata (black huckleberry) on species composition in sandplain grassland on Nantucket Island, Massachusetts. Bulletin of the Torrey Botanical Club, 122, 124-133.

Heckenberger, M.J., Petersen, J.B. \& Sidell, N.A. (1992) Early evidence of maize agriculture in the Connecticut River Valley of Vermont. Archaeology of Eastern North America, 20, 125-149.

Holmes, R.D., Hertz, C.D. \& Mulholland, M.T. (1997) Historic cultural land use study of lower Cape Cod. University of Massachusetts Archaeological Services, Amherst.

Jackson, S.T. \& Dunwiddie, P.W. (1992) Pollen dispersal and representation on an offshore island. New Phytologist, 122, 187-202.

Jacobson, G.L. Jr \& Grimm, E.C. (1986) A numerical analysis of holocene forest and prairie vegetation in central Minnesota. Ecology, 67, 958-966.

Jenkins, J. (1982) Outline of the vegetation of Nantucket and its recent changes. Center for Environmental Studies, Williams College, Williamstown, MA.

Jones, A. (1995) Grassland bird newsletter. Center for Biological Conservation. Massachusetts Audubon Society, 111, 1-4.

Kaland, P.E. (1986) The origin and management of Norwegian coastal heaths as reflected by pollen analysis. Anthropogenic indicators in pollen diagrams (ed. K.E. Behred), pp. 19-36. A.A. Belkema, Rotterdam.

Kurczewski, F.E. (1998) Distribution, status, evaluation, and recommendations for the protection of Tachysphex pechumani Krombein, the antennal-waving wasp. Natural Areas Journal, 18, 242-254.

Kurczewski, F.E. (1999) Historic and prehistoric changes in the Rome, New York pine barrens. Northeastern Naturalist, 6, 327-340.

Kurczewski, F.E. \& Boyle, H.F. (2000) Historical changes in the pine barrens of central Suffolk County, New York. Northeastern Naturalist, 7, 95-112.

Landres, P.B., Morgan, P. \& Swanson, F.J. (1999) Overview of the use of natural variability concepts in managing ecological systems. Ecological Applications, 9, 1179-1188.

Lavers, C. \& Haines-Young, R. (1993) The impact of afforestation on upland birds in Britain. Ecological effects of afforestation (ed. C. Watkins), pp. 127-152. CAB International, Wallingford, UK.

Lawton, J. (1997) The science and non-science of conservation biology. Oikos, 79, 3-5. 
Leach, M.K. \& Givnish, T.J. (1996) Ecological determinants of species loss in remnant prairies. Science, 273, 1555-1558.

Leahy, C., Mitchell, J.H. \& Conuel, T. (1996) The nature of Massachusetts. Addison-Wesley Publishing Co, New York.

Little, E.A. (1981) Nantucket Algonquian studies \#6: essay on Nantucket timber. Nantucket Historical Association, Nantucket, MA.

Luedtke, B.E. (1988) Where are the late woodland villages in eastern Massachusetts? Bulletin of the Massachusetts Archaeological Society, 49, 58-65.

Mann, C.C. (2002) '1491'. The Atlantic Monthly, 289, 41-53.

Marks, P.L. (1983) On the origin of the field plants of the northeastern United States. American Naturalist, 122, 210228.

Martin, C. (1973) Fire and forest structure in the aboriginal eastern forests. The Indian Historian, 6, 38-54.

Massachusetts Historical Commission (MHC) (1987) Historic and archaeological resources of Cape Cod and the Islands. MHC, Office of the MA Secretary of State, Boston.

Massachusetts Natural Heritage and Endangered Species Program (MNHESP) (2001) Biomap - guiding land conservation for biodiversity in Massachusetts. Executive Office of Environmental Affairs, Boston.

McAndrews, J.H. (1988) Human disturbance of North American forests and grasslands: the fossil pollen record. Vegetation history (eds B. Huntley and T. Webb), pp. 673-697. Kluwer, New York, NY.

McBride, K.A. (1990) The historical archaeology of the Mashantucket Pequots, 1637-1900: a preliminary analysis. The Pequots in southern New England: the fall and rise of an American Indian Nation (eds L.M. Hauptman and J.D. Wheery), pp. 96116. University of Oklahoma Press, Norman.

McCaffrey, C.A. (1973) An ecological history of the Province Lands, Cape Cod National Seashore. Report No. 1, University of Massachusetts - National Park Service Research Unit. Wellfleet, MA.

Medeiros, P. (1992) A proposal for an Adirondack primeval. The Wildlands Project: plotting a North American wilderness recovery strategy. Wild Earth, Special Issue, pp. 32-42. The Cenozoic Society, Canton, NY.

Mehrhoff, L.J. (1997) Thoughts on the biogeography of grassland plants in New England. Grasslands of Northeastern North America (eds P.D. Vickery and P.W. Dunwiddie), pp. 15-23. Massachusetts Audubon Society, Lincoln, MA.

Motzkin, G., Ciccarello, S.C. \& Foster, D.R. (2002) Frost pockets on a level sand plain: does variation in microclimate help maintain persistent vegetation patterns? Journal of the Torrey Botanical Society, 129, 154-163.

Motzkin, G., Foster, D., Allen, A., Harrod, J. \& Boone, R. (1996) Controlling site to evaluate history: vegetation patterns of a New England sand plain. Ecological Monographs, 66, 345-365.

Motzkin, G., Patterson, W.A. III \& Foster, D.R. (1999) A historical perspective on pitch pine-scrub oak communities in the Connecticut Valley of Massachusetts. Ecosystems, 2, 255-273.

Mulholland, M.T., Donta, C. \& Arcuti, T.L. (1998) Community archaeological reconnaissance survey of Chilmark, Massachusetts. University of Massachusetts Archaeological Services, Report UM-255. Environmental Institute, University of Massachusetts, Amherst, MA.
Neidich, C. (1980) The Hempstead Plains and the birdfoot violet. Long Island Forum, 43, 108-115.

Niering, W.A. (1981) The role of fire management in altering ecosystems. Fire regimes and ecosystem properties, pp. 489510. General Technical Report WO-26, US Forest Service. Washington, DC.

Niering, W.A. \& Dreyer, G.D. (1989) Effects of prescribed burning on Andropogon scoparius in postagricultural grasslands in Connecticut. American Midland Naturalist, 122, 88102.

Norderhaug, A., Ihse, M. \& Pedersen, O. (2000) Biotope patterns and abundance of meadow plant species in a Norwegian rural landscape. Landscape Ecology, 15, 201218.

Norment, C. (2002) On grassland bird conservation in the Northeast. The Auk, 119, 271-279.

O'Callaghan, E.B. (1850) Governor Dongan's report on New York. The documentary history of New York, Vol. I. Weed, Parsons and Co, Albany NY.

Odgaard, B.V. \& Rasmussen, P. (2000) Origin and temporal development of macro-scale vegetation patterns in the cultural landscape of Denmark. Journal of Ecology, 88, 733-748.

OECD (2001) The environmental impacts of agriculture on landscapes. Environmental indicators for agriculture. Methods and results. Organization for Economic Cooperation and Development, Paris.

Ogden, J.G. III (1958) Wisconsin vegetation and climate on Martha's Vineyard, Massachusetts. PhD Dissertation, Yale Univesity, New Haven, CT.

Ogden, J.G. III (1961) Forest history of Martha's Vineyard, Massachusetts. I. Modern and pre-colonial forests. American Midland Naturalist, 66, 417-430.

Olmsted, C.E. (1937) Vegetation of certain sand plains of Connecticut. The Botanical Gazette, 99, 209-300.

Parshall, T., Foster, D.R., Faison, E., MacDonald, D. \& Hansen, B.C.S. (2003) Long-term vegetation and fire dynamics of pitch pine-oak forests on Cape Cod, Massachusetts. Ecology, in press.

Patterson, W.A. III \& Backman, A.E. (1988a) Fire and disease history of forests. Vegetation history (eds B. Huntley and T. Webb, III), pp. 603-632. Kluwer Academic Publishers, Dordrecht, The Netherlands.

Patterson, W.A. III \& Backman, A.E. (1988b) Vegetation and fire history of Myles Standish State Forest. University of Massachusetts Cooperative Forestry Research Unit Report no. 2, Amherst, MA.

Patterson, W.A. III \& Sassaman, K.E. (1988) Indian fires in the prehistory of New England. Holocene human ecology in northeastern North America (ed. G.P. Nicholas), pp. 107135. Plenum, New York.

Patterson, W.A. III, Saunders, K.E. \& Horton, L.J. (1983) Fire regimes of Cape Cod National Seashore. USDI NPS North Atlantic Region Office of Scientific Studies Report OSS83-1. National Park Service, Boston, MA.

Peterken, G.F. (1977) Habitat conservation priorities in British and European woodlands. Biological Conservation, 1, 223236.

Pyne, S.J. (1982) Fire in America. Princeton University Press, Princeton, NJ. 
Raleigh, L. (2000) Land-use history of Long Point Refuge. The Trustees of Reservations, Vineyard Haven, MA.

Raup, H.M. (1937) Recent changes in climate and vegetation in southern New England and adjacent New York. Journal of the Arnold Arboretum, 18, 79-117.

Rice, M.A. (1946) Trees and shrubs of Nantucket. Edwards Brothers, Inc, Ann Arbor, MI.

Robertson, J.G.M. (1990) Habitat analysis from infra-red aerial photographs and the conservation of birds in Swedish agricultural landscapes. Ambio, 19, 195-203.

Rudnicky, J.L., Patterson, W.A. III \& Cook, R.P. (1997) Experimental use of prescribed fire for managing grassland bird habitat at Floyd Bennett Field, Brooklyn, New York. Grasslands of northeastern North America: ecology and conservation of native and agricultural landscapes (eds P.D. Vickery and P.W. Dunwiddie), pp. 99-118. Massachusetts Audubon Society, Lincoln, MA.

Russell, H.S. (1980) Indian New England before the Mayflower. University Press of New England, Hanover, NH.

Russell, H.S. (1982) A long deep furrow: three centuries of farming in New England. University Press of New England, Hanover, NH.

Russell, E.W.B. (1983) Indian set fires in the forests of the northeastern United States. Ecology, 64, 78-88.

Russell, E.W.B. \& Davis, R.B. (2001) Five centuries of changing forest vegetation in the northeastern United States. Plant Ecology, 155, 1-13.

Schweitzer, D.F. \& Rawinski, T.J. (1987) Northeastern pitch pine/scrub oak barrens. Eastern heritage task force. The Nature Conservancy, Boston, MA.

Sharpe, B. (1994) New England grasslands. Sanctuary, November/December, 12-16.

Singer, M.C., Thomas, C.D. \& Parmesan, C. (1993) Rapid human-induced evolution of insect-host associations. Nature, 366, 681-683.

Steel, J. (1999) Losing ground: an analysis of recent rates and patterns of development and their effects on open space in Massachusetts, 2nd edn. Massachusetts Audubon Society, Lincoln, MA.

Stevens, A. (1996) The paleoecology of coastal sand plain grasslands on Martha's Vineyard, Massachusetts. PhD Dissertation, University of Massachusetts, Amherst.

Sugita, S., Gaillard, M.J. \& Brostrom, A. (1999) Landscape openness and pollen records: a simulation approach. Holocene, 9, 409-421.

Sutherland, W.J. \& Hill, D.A. (1995) Managing habitats for conservation. Cambridge University Press, Cambridge.

Swetnam, T.W., Allen, C.D. \& Betancourt, J.L. (1999) Applied historical ecology: using the past to manage for the future. Ecological Applications, 9, 1189-1206.

Taylor, N. (1923) The vegetation of Long Island - Part I: The vegetation of Montauk - a study of grassland and forest. Memoirs of the Brooklyn Botanic Garden, Brooklyn, NY.

The Trustees of Reservations (TTOR) (1999) Conserving our common wealth - a vision for the Massachusetts Landscape. The Trustees of Reservations, Beverly, MA.
Thorbahn, P.F. (1988) Where are the late woodland villages in southern New England? Bulletin of Massachusetts Archaeological Society, 49, 46-57.

Thoreau, H.D. (1857; [1951]) Cape Cod. Bramhall House, New York.

Tiffney, W.N. Jr (1997) The role of nurient-level control in maintaining and restoring lowland heaths: British and northern European techniques of potential application in northeastern North America. Grasslands of northeastern North America (eds P.D. Vickery and P.W. Dunwiddie), pp. 69-78. Massachusetts Audubon Society, Lincoln, MA.

Tveskov, M.A. (1992) Early woodland settlement and subsistence on Block Island, Rhode Island. MA Thesis, University of Connecticut, Storrs.

Tzedakis, P.C. (1992) Effects of soils on the Holocene history of forest communities, Cape Cod, Massachusetts, USA. Geographic Physique et Quaternaire, 46, 113-124.

United States Coast and Geodetic Survey (USCGS) (1836-1880) Maps of Long Island, New York. Harvard Forest Archives, Petersham, MA.

Vaughan, A. (1979) New England frontier: puritans and Indians, 1620-1675. Little and Brown, Boston, MA.

Verrazano, G. (1524) Narragansett Bay. Sailors' narratives of voyages along the New England coast 1524-1624 (ed. G.P. Winship), pp. 1-23 (1968). Burt Franklin, New York.

Vickery, P.D. (2002) Effects of the size of prescribed fire on insect predation of northern blazing star, a rare grassland perennial. Conservation Biology, 16, 413-421.

Vickery, P.D. \& Dunwiddie, P.W. (1997) Introduction: Grasslands of Northeastern North America (eds P.D. Vickery and P.W. Dunwiddie), pp. 1-13. Massachusetts Audubon Society, Lincoln, MA.

Vickery, P.D., Enz, T. \& Dunwiddie, P.W. (1996) Influence of fire on the reproductive ecology of northern blazing star, a rare grassland perennial of northeastern North America. Bulletin of the Ecological Society of America, 77, 458.

Watkins, C. (ed.) (1993) Ecological effects of afforestation. CAB International, UK.

Whitehead, D.R. (1979) Late-glacial and postglacial vegetational history of the Berkshires, western Massachusetts. Quaternary Research, 12, 333-357.

Whitney, G.G. (1994) From coastal wilderness to fruited plain. Cambridge University Press, Cambridge.

Wilson, E.O. (2002) The future of life. Knopf Publishers, New York.

Winkler, M.G. (1985) A 12,000-year history of vegetation and climate for Cape Cod, Massachusetts. Quaternary Research, 23, 301-312.

Winne, J.C. (1997) History of vegetation and fire on the Pineo Ridge pine grassland barrens of Washington County, Maine. Grasslands of northeastern North America: ecology and conservation of native and agricultural landscapes (eds P.D. Vickery and P.W. Dunwiddie), pp. 25-52. Massachusetts Audubon Society, Lincoln, MA.

Wood, W. (1634) (1977) New England's prospect. University of Massachusetts Press, MA. 
BIOSKETCHES

Glenn Motzkin is a plant ecologist at Harvard Forest whose work focuses on historical ecology and its application to conservation in New England.

David Foster is a plant ecologist and palaeoecologist who combines historical and modern approaches to vegetation analyses in order to interpret and conserve natural and cultural landscapes.

\section{APPENDIX I}

Early historical references to open lands and fire in the coastal region from Massachusetts to Long Island, NY. With few exceptions, only sixteenth- and seventeenth century references are included. Numerous references to forests and woodlands from every town across the region are not included, nor are references to Native American place-names. Additional references to open lands and Native American burning and fields in the north-eastern US are found in Day (1953), Russell (1983) and Motzkin (HF Archives 2002).

\section{Long Island, NY}

1. 1665: Easthampton (including Montauk) - 'The inhabitants forever to have full and free liberty at any time to cut grass on said lands, and for feeding of cattle, but not till the corn planted by the Indians, shall be taken off...Indians not to set fire to the grass before the month of March, without consent of the town...' (Taylor, 1923).

2. 1670: Hempstead Plains - "Toward the middle of Long Island lyeth a plain, sixteen miles long and four broad, upon which plain grows very fine grass, that makes excellent good hay, and is very good pasture for sheep and other cattel; where you shall find neither stick nor stone to hinder the horses' heels or endanger them in their races.' (Daniel Denton in Neidich, 1980; note that European settlement began in 1644 according to Neidich; Whitney, 1994).

3. 1672: 'On Long Island the cessation of Indian-set fires and the regrowth of the underwood prompted the Governor to order every inhabitant in 1672 to turn out for four days of brush cutting." (Wood in Whitney, 1994).

4. 1687: Hempstead - 'having a plain of upwards of 40000 acres of good pasture without a stick on it as for its value I believe Judge Palmer would think himself obliged to anyone that would give him L200 for it.' (Gov. Dongan in O'Callaghan, 1850).

5. 1744: Hempstead - 'At four o'clock, going across this great plain, we could see almost as good a horizon around us as when one is at sea, and in some places of the plain, the latitude might be taken by observation at noonday. It is about sixteen miles long. The ground is hard and gravelly, the road very smooth but indistinct, and intersected by several roads, which make it difficult for the stranger to find the way. There is nothing but long grass upon this plain, only in some particular spots small oak brush, not a foot high. Near Hampstead there are several pretty winding brooks that run thro' this plain... Just after we came out of the plains and sunk into the woods...' (Dr. Alexander Hamilton in Neidich, 1980).

\section{Cape Cod, MA}

6. 1603: On Cape Cod where Martin Pring was cutting a cargo of sassafras: 'The Indians dissembled a jesting manner as they left yet not long after, even the day before our departure, they set fire on the woodes where wee wrought, which we did behold to burne for a mile space.' (M. Pring in Day, 1953; Russell, 1983).

7. 1605: '...rather high, and consists of sand, which is very conspicuous as one comes from the sea... There is a large extent of open country along the shore before reaching the woods, which are very attractive and beautiful (Champlain in Holmes et al., 1997).

8. 1605: '... After we had entered (Nauset Harbor), we found the place very spacious, being perhaps three or four leagues in circuit, entirely surrounded by little houses, around each of which there was as much land as the occupant needed for his support...' (Champlain in Holmes et al., 1997).

9. 1605: Nauset Harbor - 'Before reaching their cabins, we entered a field planted with Indian corn in the manner above described. The corn was in flower, and five and a half feet high. There was some less advanced, which they plant later. We saw many Brazilian beans, and many squashes of various sizes, very good for eating; some tobacco, and roots which they cultivate, the latter having the taste of an artichoke. The woods are filled with oaks, nut trees, and beautiful cypresses 
[cedars], which are of a reddish color and have a very pleasant odor. There were also several fields entirely uncultivated, the land being allowed to remain fallow. When they wish to plant it they set fire to the weeds, and then work it over with their wooded spades.' (Champlain in Holmes et al., 1997).

10. 1606: 'they (Indians) are not so much great hunters as good fisherman and tillers of the lands.' (Champlain in Friedman, 1993).

11. 1614: Cape Cod - only a headland of high hils of sand, overgrowne with shrubbie pines, hurts, and such trash; but an excellent harbor for all weathers. (J. Smith in Holmes et al., 1997).

12. 1620: Long Point, Provincetown - 'On this side where we lay is the bay, and the further side the sea; the ground or earth, sand hills much like the downs in Holland, but much better; the crust of the earth a spit's depth, juniper, birch, holly, vines, some ash, walnut; the wood for the most part open and without underwood, fit either to go or ride in.' (Bradford \& Winslow in McCaffrey, 1973; Whitney, 1994).

13. 1620: Truro - 'When the Pilgrims explored the area in late 1620, they found cleared fields and a cache of corn in the Corn Hill area. The Native Americans probably did not have a nucleated village, but had dispersed farmsteads in the region (Thorbahn, 1988 in Holmes et al., 1997, p. 40).' Indian corn fields also in Eastham and at 'Great Hollow' Truro(?) (Holmes et al., 1997, p. 48). Village Pond, North Truro: 'a good quantity of clear ground where the Indians had formerly set corn.' (Bradford in Dunwiddie \& Adams, 1995).

14. 1620: Outer Cape - '...found much plain ground, about fifty acres, fit for the plow, and some signs where the Indians had formerly planted their corn...' (Friedman, 1993).

\section{Martha's Vineyard, Nantucket and Elizabeth Islands, MA}

15. 1602: Martha's Vineyard (Cape Pogue or Chappaquiddick) or Noman's Island? - "chiefly ...beeches and cedars, the outward parts all overgrown with bushie trees, 3 or 4 foot in height, which bear some kind of fruits...raspeberries, gooseberries, hurtleberries... an incredible store of vines... where they run upon every tree... that we could not go for treading upon them." (Archer in Dunwiddie \& Adams, 1994).

16. 1602: 'On the outside of this Island are many plaine places of grasse, abundance of Strawberies \& other berries...'(Brereton, $1602[1983])$.

17. 1664: Nantucket - 'If any land on any part of the island be set fire to by any Indian so that the land or grass be Burnt to any considered value as to a quarter of a mile or more the Indians in whose juridiction so ever it be shall be fined 20 pound, except it be in the month of April.' (Little, 1981).

18. 1669: Martha's Vineyard - '...land (at) Meeshackett containing I judge 63 acres more or Less Bound with the Shrubed plain or Comon Land on the North...' (deed referenced in Banks, 1911).

\section{Southern New England}

19. 1524: Narragansett Bay - 'open plains twenty-five or thirty leagues in extent, entirely free from trees or other hinderances (and forests that) might all be traversed by an army ever so numerous.' (Verrazano in Pyne, 1982).

20. 1524: Russell (1980) refers to an account by Verrazano of the 'multitude of fires that met his eyes.' (Raleigh, 2000). Verrazano saw 'huge fires...on the seashores.' (Russell, 1983).

21. 1602: north shore of Buzzards Bay? - 'we stood awhile like men ravished at the beautie and delicacie of this sweet soile...Meadowes very large and full of greene grasse; even the most woody places... doe grow so distinct and apart, one tree from another, upon greene grassie ground, somewhat higher than the Plaines, as if Nature would shew her selfe above her power, artificial.' (Brereton in Dunwiddie \& Adams, 1994; Whitney, 1994).

22. 1621: Taunton River, southeastern MA - The ground was 'very good on both sides, it being for the most part cleared.' (Winslow \& Hopkins in Carroll, 1973).

23. 1621: Plymouth - 'But their greatest labor was spent in getting wood, which was "half a quarter of an English mile" from the settlement.' (Carroll, 1973).

24. 1622: '...the Pilgrims decided to establish their plantation at Plymouth "on high ground where there is a great deale of land cleared, and hath been planted with corne three or four years agoe". (Bradford \& Winslow in Whitney, 1994).

25. 1622: Along the Taunton River, southeastern MA - 'Thousands of men have lived there, which dyed in a great plague not long since; and pitty it was and is to see so many goodly fieldes, $\&$ so well seated, without men to dresse and manure the same.' (Bradford \& Winslow in Whitney, 1994).

26. 1620s: '...two men, becoming lost, wandered onto a "place where the Savages had burnt the space of five miles in length".' (Day, 1953).

27. 1630: Salem, Massachusetts - 'I am told that about three miles from us a man may stand on a little hilly place and see divers thousands of acres of ground as good as need be, and not a tree in the same.' (Higginson, in Pyne, 1982 and Whitney, 1994; Cronon, 1983). 
28. 1632: The Indians: 'use not to winter and summer in one place, for that would be a reason to make fuell scarse.' (Morton in Cronon, 1983).

29. 1633: Plymouth Colony - 'The Indians were convenient scapegoats, but more timber areas were seared by the settlerapplied torch than by native Americans in search of game. At first, legislation sought to limit the burning season. The authorities of Plymouth Colony noted in 1633 that 'many have sustayned (sic) great damage by the indiscreet frying of the woods.' (Cox et al., 1985).

30. 1633: 'In the spring of 1633, the Plymouth coloney went to work clearing the woods for cornfields, "the Lord having mitigated their labours by the Indians frequent fiering of the woods, (that they may not be hindered in hunting Venison, and Beares in the Winter season) which makes them thin of Timber in many places, like our Parkes in England'.' Johnson in Day, 1953; Whitney, 1994).

31. 1600s: 'The woods of Massachusetts were in many places so open that from a high place cattle could be seen for a distance of three miles, and deer and turkeys a mile away.' (Pyne, 1982).

32. 1630s? Josselyn refers to open woodlands (Russell, 1983).

33. 1634: 'The next commodity the land affords is good store of woods, and that not only such as may be needful for fuel but likewise for the building of ships and houses and mills and all manner of water-work about which wood is needful. The timber of the country grows straight and tall, some trees being twenty, some thirty foot high, before they spread forth their branches; generally the trees be not very thick, though there may be many that will serve for mill posts, some being three foot and a half over. And whereas it is generally conceived that the woods grow so thick that there is no more clear ground than is hewed out by labor of man, it is nothing so, in many places diverse acres being clear so that one may ride ahunting in most places of the land if he will venture himself for being lost. There is no underwood saving in swamps and low grounds that are wet, in which the English get osiers and hasles (hazels) and such small wood as is for their use. Of these swamps, some ten, some twenty, some thirty miles long, being preserved by the wetness of the soil wherein they grow; for it being the custome of the Indians to burne the wood in November, when the grasse is withered, and leaves are dryed, it consumes all the underwood, and rubbish, which otherwise would overgrow the Country, making it impassable, and spoil their much affected hunting so that by this means in those places where the Indians inhabit, there is scarce a brush or bramble, or any cumbersome underwood to bee seene in the more champion ground. Small wood, growing in these places where the fire could not come, is preserved. In some places, where the Indians died of the plague some fourteen years ago, is much underwood, as in the midway betwixt Weeaguscus and Plymouth, because it hath not been burned. Certain rivers stopping the fire from coming to clear that place of the country hath made it unuseful and troublesome to travel through, insomuch that it is called ragged plain because it tears and rents the clothes of them that pass.' [Wood, 1634 (1977); Day, 1953; Patterson and Sassaman, 1988; Raleigh, 2000].

34. 1634: 'These marshes be rich ground and bring plenty of hay, of which the cattle feed and like as if they were fed the best upland hay in New England, of which likewise there is great store which grows commonly between the marshes and the woods. This meadow ground lies higher than the marshes, whereby it is freed from the overflowing of the seas; and besides this, in many places where the trees grow thin there is good fodder to be got amongst the woods.' [Wood, 1634 (1977)].

35. 1636: Rhode Island - the Narragansetts 'have every one 2 fields which after the first 2 years they lett one field rest each year, \& that keeps their ground continually in hart.' (Winthrop in Whitney, 1994). However, 'a long-term fallow or a slash-andburn system appears to have been the norm on most sites in the Northeast. Sites were cropped from 8 [Wood, 1634 (1977)] to 30 years (Pratt in Whitney, 1994).

36. 1630s: 'The savages are accustomed to set fire in all places where they come; and to burne it, twize a year, vixe at the Spring, and the fall of the leafe. The reason that moves them to do so, is because it would otherwise be so overgrown with underweedes that it would be all a coppice wood, and the people would not be able in any wise to passe through the Country out of a beaten path... The burning of the grasse destroys the underwoods, and so scorcheth the elder trees, that it shrinkes them, and hinders their growth very much: So that hee that will look to finde large trees, and good tymber, must not depend upon the help, of a wooden prospect to finde them on the upland ground; but must seek for them, (as I and others have done) in the lower grounds where the grounds are wett when the Country is fired...For when the fire is once kindled it dilates and spreads itself against as with the winds; burning continually night and day until a shower of rain falls to quench it. And this custom of firing the country is the meanes to make it passable, and by that meanes the trees growe here, and there as in our parkes.' (Thomas Morton in Day, 1953; Pyne, 1982; Dunwiddie \& Adams, 1994).

37. 1630s: Morton noted that such practices forced the immigrants into a pattern of protective burning around the settlements 'to prevent the Dammage that might happen by neglect thereof, if the fire should come neers those howses in our absence.' 'The Salvages by this Custome of theirs, have spoiled all the rest (of the countryside): for this Custome hath been continued from the beginninge.' (Thomas Morton in Pyne, 1982).

38. 1643: Narragansetts - '...if a spark fall into the Drie wood, (it) burns up the Country, (although this burning of the Wood to them they count a benefit, both for destroying of vermin, and keeping downe the Weeds and thickets).' (Roger Williams in Day, 1953). 
39. 1640s: The Indians 'hunted all the Country over, and for the expedition of their hunting voyages, they burnt up all the underwoods in the Countrey, once or twice a yeare and therefore as Noble men in England possessed great Parkes, and [as] the King, great Forrests in England onely for their game...' (Williams in Cronon, 1983 and Whitney, 1994).

40. 1640s: 'This question they [the Indians] oft put to me: Why come the Englishmen hither? and measuring others by themselves; they say, It is because you want firing: for they, having burnt up the wood in one place, (wanting draughts [animals] to bring wood to them) they are faine to follow the wood; and so to remove to a fresh new place for the woods sake.' (Roger Williams in Cronon, 1983).

41. 1679: Massachusetts Bay Colony - 'Upon hearing "that great damage hath hapned to severall persons in the outskirt plantations by Indians kindling fires in the woods", the Massachusetts Bay in 1679 summarily subjected the Indian inhabitants of the colony to the same stringent laws that governed the Europeans' use of fire.' (Whitney, 1994). 